\title{
38. STRUCTURAL AND STRATIGRAPHIC EVOLUTION OF THE SUMISU RIFT, IZU-BONIN ARC ${ }^{1}$
}

\author{
Adam Klaus, ${ }^{2,3}$ Brian Taylor, ${ }^{2}$ Gregory F. Moore, ${ }^{2}$ Mary E. MacKay, ${ }^{2}$ Glenn R. Brown, ${ }^{4}$ \\ Yukinobu Okamura, ${ }^{5}$ and Fumitoshi Murakami ${ }^{5}$
}

\begin{abstract}
The Sumisu Rift, which is $~ 120 \mathrm{~km}$ long and $30-50 \mathrm{~km}$ wide, is bounded to the north and south by structural and volcanic highs west of the Sumisu and Torishima calderas and longitudinally by curvilinear border fault zones with both convex and concave dips. The zigzag pattern of normal faults (average strikes $\mathrm{N} 23^{\circ} \mathrm{W}$ and $\mathrm{N} 5^{\circ} \mathrm{W}$ ) indicates fault formation in orthorhombic symmetry in response to $\mathrm{N} 76^{\circ} \pm 10^{\circ} \mathrm{E}$ extension, orthogonal to the volcanic arc. Three oblique transfer zones divide the rift along strike into four segments with different fault trends and uplift/subsidence patterns. Differential strain across the transfer zones is accommodated by interdigitating, rift-parallel faults and some cross-rift volcanism, rather than by strike- or oblique-slip faults. From estimates of extension ( $2-5 \mathrm{~km}$ ), the age of the rift ( $2 \mathrm{Ma})$, and the accelerating subsidence, we infer that the Sumisu Rift is in the early syn-rift stage of backarc basin formation. Following an early sag phase, a half graben formed with a synthetically faulted, structural rollover facing large-offset border fault zones. In the three northern rift segments, the largest faults are on the arc side and dip $60^{\circ}-75^{\circ} \mathrm{W}$, whereas in the southern segment they are on the west side and dip $25^{\circ}-50^{\circ} \mathrm{E}$. The present, "full graben" stage is dominated by hanging-wall antithetic faulting, basin widening by footwall collapse, and a concentration of subsidence in an inner rift. The hanging wall collapses but not necessarily as a result of border fault propagation from adjacent rift segments. Whereas the border faults may penetrate the rheologically weak lithosphere $\left(T_{\mathrm{e}} \sim 3 \mathrm{~km}\right)$, many of the hanging-wall and footwall collapse structures are detached only a few kilometers below the seafloor. Where drilled, the arc margin has been uplifted 1.1 $\pm 0.5 \mathrm{~km}$ concurrently with $\sim 1.1 \mathrm{~km}$ of rift basin subsidence. Backarc volcanism, usually erupted along faults, occurs in the rift and along the proto-remnant arc during both stages. A linear zone of weakness caused by the greater temperatures and crustal thickness along the arc volcanic line controls the initial locus of rifting. Rifts are better developed between the arc edifices; intrusions may be accommodating extensional strain adjacent to the arc volcanoes. No obvious correlations are observed between the rift structures and preexisting cross-arc trends. Episodic eruptions of the arc volcanoes are the dominant sediment source; sediment is primarily fed into the northern and southern ends of the rift basin. Sediments are distributed throughout the region by eruptive events and redeposited in the rift basin by unconfined mass flows. Extremely high sedimentation rates, up to $6 \mathrm{~m} / 1000$ $\mathrm{yr}$ in the inner rift, have kept pace with syn-rift faulting, create a smooth basin floor, and result in sediment thicknesses that mimic the differential basin subsidence.
\end{abstract}

\section{INTRODUCTION AND PREVIOUS WORK}

Although the active rifting of intraoceanic island arcs was first proposed about 20 yr ago (Karig, 1971; Packham and Falvey, 1971), the extensional mechanisms associated with stretching arc lithosphere remain poorly known. Investigations using swath-mapping, seismic, sedimentologic, petrologic, and heat-flow techniques have begun to reveal the surficial pattern of extensional strain, the nature and structural control of rift volcanism, sedimentation, and hydrothermal circulation, as well as the influence of the line of active arc volcanoes on rifting processes (Sibuet et al., 1987; Taylor et al., 1990a; Wright et al., 1990).

One of the better studied active arc rift systems occurs south of Honshu, Japan (Fig. 1). Bathymetric depressions west of the Izu-Bonin island arc were first observed by Mogi (1968) and Hotta (1970). Investigations using reconnaissance seismic and bathymetric data (Karig and Moore, 1975; Honza and Tamaki, 1985) were sufficient to identify the presence and gross morphology of these fault-bounded basins and allowed the hypothesis that they were extensional in origin.

Sumisu Rift (Fig. 1), in the Izu-Bonin island arc, has been the focus of recent investigations by the Hawaii Institute of Geophysics and the

'Taylor, B., Fujioka, K., et al., 1992. Proc. ODP, Sci. Results, 126: College Station. TX (Ocean Drilling Program).

${ }^{2}$ Department of Geology and Geophysics, University of Hawaii, 2525 Correa Rd. Honolulu, HI 96822, U.S.A.

${ }^{3}$ Present address: Ocean Research Institute, University of Tokyo, 1-15-1 Minamidai, Nakano, Tokyo 164, Japan.

${ }^{4}$ Department of Geology, University of Toronto, 170 College Street, Toronto, Ontario M5S IA1, Canada.

${ }^{5}$ Geological Survey of Japan, 1-1-3 Higashi, Tsukuba, Ibaraki 305, Japan.
Geological Survey of Japan. Densely spaced single-channel seismic data have been collected to define shallow rift structures (Murakami, 1988; Brown and Taylor, 1988). SeaMARC II sidescan sonar imagery and bathymetry (Brown and Taylor, 1988; Taylor et al., 1988a, 1988b) and SeaBeam bathymetry (Taylor et al., 1990a) investigations mapped the surficial distribution of faults, volcanoes, and sediments. Additional sedimentologic (Nishimura and Murakami, 1988), volcanic (Fryer et al., 1990; Hochstaedter et al., 1990), and heat-flow (Yamazaki, 1988; Taylor et al., 1990a) studies have begun to document the sediment and volcanic rock types, processes, and distribution, as well as the nature of hydrothermal circulation.

Extension of the Izu-Bonin Arc has resulted in the formation of asymmetric rift basins located adjacent to the active volcanic arc that are $20-60 \mathrm{~km}$ wide by $20-120 \mathrm{~km}$ long. The rifts are bounded by high-angle, normal fault zones and are separated along strike by structural highs and chains of submarine volcanoes (Honza and Tamaki, 1985; Taylor et al., 1984; Brown and Taylor, 1988; Murakami, 1988). Individual rift basins are segmented along strike by cross-trending transfer zones that link opposing border fault zones (Taylor et al., 1990a; Taylor and Shipboard Scientific Party, 1990).

Structural control of volcanism is commonly observed in these backarc rift basins where extrusive volcanic rocks (1) are concentrated along cross-trending accommodation zones, (2) are elongate parallel to rift faulting, (3) form clusters of aligned vents along rift faults, and (4) extend outward onto the rift margins (Brown and Taylor, 1988; Taylor et al., 1990a). Within the rift basins, the presence of geochemically "backarc basin basalts" indicates that a magma source with little influence by arc components is present even at the earliest stages of arc rifting (Fryer et al., 1990; Hochstaedter et al., 1990; Gill et al., this volume). Active backarc rift basin hydrothermal 


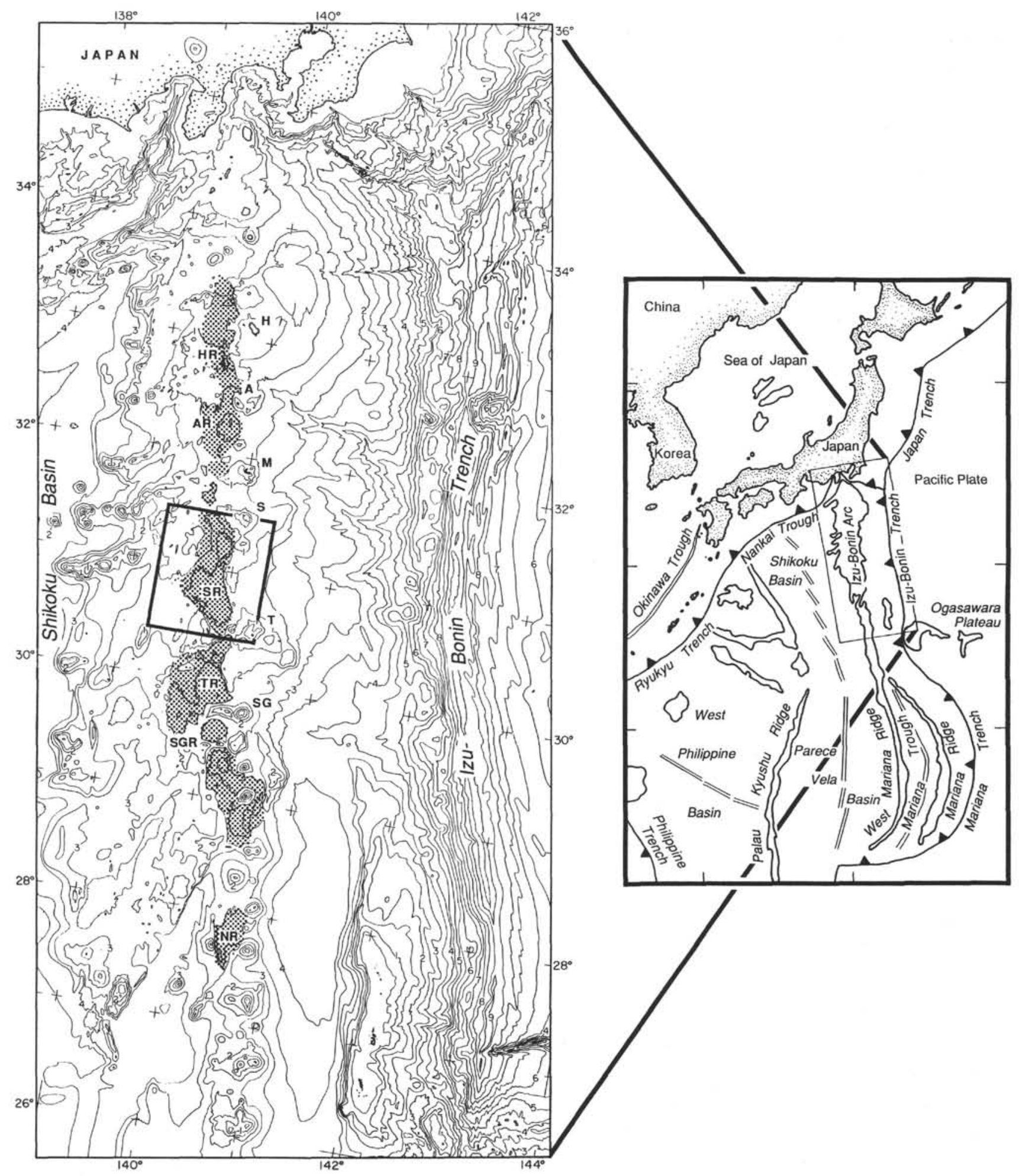

Figure 1. The box shown on the generalized tectonic map of the western Pacific outlines the area of the bathymetric map of the Izu-Bonin arc-trench system shown on the left (Taylor et al., 1990b). Arc rifts (HR = Hachijo, AR = Aoga Shima, SR = Sumisu, TR = Torishima, SGR = Sofu Gan, NR = Nishino Shima) are stippled, and the nearby island-arc volcanoes are labeled $(\mathrm{H}=$ Hachijo Jima, $\mathrm{A}=$ Aoga Shima, $\mathrm{M}=$ Myojin Sho, $\mathrm{S}=\mathrm{Sumisu}$ Jima, $\mathrm{T}=\mathrm{Torishima}$, and $\mathrm{SG}=$ Sofu Gan). The Sumisu Rift study area shown in Figure 2 is outlined. The contour interval is $0.5 \mathrm{~km}$. 
circulation, evidenced by high and variable heat flow, may occur along rift faults and/or through permeable rift basin sediments (Yamazaki, 1988; Taylor et al., 1990a).

Sediment input to the Izu-Bonin rift basins is dominated by volcaniclastic sediments erupted from the adjacent volcanic arc that are distributed throughout the region by eruptive events and redeposited in the rift basin by submarine mass flows (Nishimura and $\mathrm{Mu}$ rakami, 1988; Brown and Taylor, 1988). Sediment deposition is profoundly influenced by the variable subsidence of rift blocks, as well as by volcanic ridges that influence sediment transport pathways (Brown and Taylor, 1988; Nishimura and Murakami, 1988).

Before the collection of deep-penetrating multichannel seismic (MCS) data (Taylor et al., 1990b; this study) and Ocean Drilling Program (ODP) Leg 126 drilling of the Sumisu Rift (Taylor, Fujioka, et al., 1990), major questions about the rifting process remained unanswered, such as (1) the nature and structure of the pre-rift section beneath the rift basin, (2) the age of initiation of rift formation, (3) the facies and processes of syn-rift sedimentary fill, and (4) the rate of syn-rift sedimentation and basin subsidence.

In June-August 1987 as part of the site survey for Legs 125 and 126, we conducted an MCS survey of the Sumisu Rift (Fig. 2). The data acquisition and processing parameters are described in Taylor et al. (1990b). We sought to constrain the mechanisms of rifting arc lithosphere by determining the deep crustal structure of this backarc rift. In this paper we present the results of the MCS survey and the detailed tectonic interpretation permitted by integrating these data (Fig. 3) with the Leg 126 drilling data, as well as previously collected seismic and swath-mapping data (Fig. 4). Unfortunately, the overprinting of pre-rift sequences and structures by syn-rift volcanism and faulting prevented us from clearly imaging the deep structure of Sumisu Rift. Nevertheless, we were able to integrate the comprehensive data to better document the near-surface structural, volcanic, and sedimentation processes associated with rifting of the Izu-Bonin intraoceanic island arc.

\section{TECTONIC SETTING}

Subduction of the Pacific plate beneath the west Philippine plate (Fig. 1) began in the early Eocene (Karig, 1975) and by the end of the early Oligocene a 200-km-wide intraoceanic volcanic arc massif had formed (Taylor and Shipboard Scientific Party, 1990), composed of tholeiitic and boninitic volcanic rocks (Natland and Tarney, 1982). The Izu-Bonin forearc basin is a product of mid-Oligocene rifting of this Eocene and early Oligocene arc massif (Leg 126 Shipboard Scientific Party, 1989; Taylor, Fujioka, et al., 1990). Rifting of the Izu-Bonin and Mariana island arcs, followed by late Oligocene to early Miocene seafloor spreading in the Shikoku (25-15 Ma; ChamotRooke, 1989) and Parece Vela basins (30-17 Ma; Mrozowski and Hayes, 1979), formed backarc basins that separated the remnant arc (Palau-Kyushu Ridge) from the Izu-Bonin-Mariana Arc.

A second stage of Mariana Arc rifting and latest Miocene (6 Ma) to Holocene backarc spreading in the Mariana Trough has separated the Mariana Arc from its second remnant arc, the west Mariana Ridge (Hussong and Uyeda, 1982). In contrast, the Izu-Bonin Arc is still in the second stage of backarc rift formation; the rifts are forming along most of its length adjacent to the active volcanic arc (Fig. 1; Karig and Moore, 1975; Honza and Tamaki, 1985; Tamaki, 1985). These backarc rift basins are semicontinuous along strike, segmented by structural highs and chains of submarine volcanoes, and have not yet developed into the backarc spreading stage (Taylor et al., 1984, 1990a, 1990b).

\section{SUMISU RIFT ARCHITECTURE}

Sumisu Rift is located west of the frontal arc Sumisu, South Sumisu, and Torishima submarine calderas (Figs. 1 and 2). It extends $120 \mathrm{~km}$, from approximately $30.5^{\circ}$ to $31.5^{\circ} \mathrm{N}$, and is $30-50 \mathrm{~km}$ wide. It is the longest of the Izu-Bonin rifts; some structural depressions are nearly equidimensional and only $20-30 \mathrm{~km}$ across (Fig. 1). Sumisu Rift is bounded to the north and south by structural and volcanic highs west of the Sumisu and Torishima calderas and longitudinally by large-offset normal (border) fault zones that are 2-10 km wide (Figs. 3 and 5). Two to three faults accommodate the majority of the $\sim 1 \mathrm{~km}$ of surficial throw, and $>1 \mathrm{~km}$ of additional throw beneath the sedimented rift basin floor, across the border fault zones. The MCS data show that these faults dip steeply $\left(60^{\circ}-75^{\circ}\right)$, except in the southwest, where dips are $25^{\circ}-50^{\circ}$. Previous interpretations based on bathymetry and unmigrated single-channel seismic data significantly underestimated the fault dips $\left(20^{\circ}-50^{\circ}\right.$; Taylor et al., 1990a).

Sumisu Rift has two sediment depocenters that are separated at a sill depth of $2080 \mathrm{~m}$ by an en echelon ridge of extrusive volcanic rocks (Figs. 2 and 5). The North (Kita) Sumisu Basin and South (Minami) Sumisu Basin exhibit smooth sedimented basin floors that are 2100 2150 and $2200-2275 \mathrm{~m}$ deep, respectively, with gently sloping rises up to $2000 \mathrm{~m}$ deep in the north and south.

The border, and other rift-parallel, faults delineate four structural provinces across strike from east to west (Figs. 3 and 5): (1) the arc margin; (2) the inner rift, the locus of maximum subsidence and sediment thickness; (3) the outer rift; and (4) the proto-remnant arc. Oblique transfer zones also divide Sumisu Rift along strike into four segments with differing fault trends and uplift/subsidence patterns (Figs. 5 and 6). The shallowest rift segment is in the north, adjacent to Sumisu Caldera, where the faults have an average trend of $336^{\circ}$ (region D, Fig. 5). An east-trending transfer zone at $31^{\circ} 16^{\prime}-31^{\circ} 20^{\prime} \mathrm{N}$ separates this area from the north-central segment, where fault strikes average $355^{\circ}$ (regions $\mathrm{C}$ and E, Fig. 5) and the inner-rift basement is $1 \mathrm{~km}$ deeper. In the south-central segment, south of the northeasttrending central transfer zone marked by volcanic rocks, fault strikes average $339^{\circ}$ (regions B and F, Fig. 5). This is the widest segment of Sumisu Rift and differs from the two northern segments in having a second half graben in the outer rift that has subsided to nearly the same level as the inner rift. The three northern rift segments have border fault zones of larger throw on the east than on the west. In contrast, the southern segment, south of an east-trending transfer zone at $30^{\circ} 40^{\prime}-30^{\circ} 43^{\prime} \mathrm{N}$ and adjacent to Torishima Caldera and Kotori submarine volcano, has a large-offset border fault zone on the west and a gentle rollover out of the basin on the east (Figs. 3 and 5). The faults in this segment strike $333^{\circ}$ on average (region A, Fig. 5). The footwalls of the border faults, particularly those of the southern two rift segments, are uplifted and rotated away from the rift axis.

\section{ARC MARGIN}

The active frontal arc volcanoes, Sumisu Jima and Torishima, lie on the southern rim of much larger submarine calderas (Fig. 2). South Sumisu Caldera, $20 \mathrm{~km}$ south of Sumisu Jima, has a horseshoe-shaped rim $300-400 \mathrm{~m}$ below sealevel (mbsl). Kotori submarine volcano, west of Torishima, lies at the southern end of Sumisu Rift on the basement high separating the Sumisu and Torishima rifts (Fig. 2). The arc margin is bounded on the west by large-offset border fault zones north of $30^{\circ} 41^{\prime} \mathrm{N}$ and by a monocline, cut by small-offset normal faults, farther south (Figs. 2, 3, 5, and 6). To the east, the arc margin slopes gently into the forearc basin. The arc margin forms the depositional divide between the rift and forearc basins.

South of $30^{\circ} 41^{\prime} \mathrm{N}$, the arc margin forms the faulted, ramping side of a half graben and is characterized by three principal seismic units (profile 13, Fig. 3). The middle unit has high-amplitude, conformable, and relatively continuous reflectors up to $1 \mathrm{~km}(0.9 \mathrm{~s})$ thick. To the west this unit is pervasively faulted down into the rift basin. This unit unconformably overlies a sequence characterized by more chaotic (faulted) and larger amplitude reflectors; it is erosionally truncated and draped by $\sim 200-250 \mathrm{~m}(0.35 \mathrm{~s})$ of more transparent and discontinuous reflections. The uppermost seismic unit is continuous, with only minor normal fault offsets, with the uppermost rift basin sequence. It laps onto the arc margin rift flank uplift to the north. 


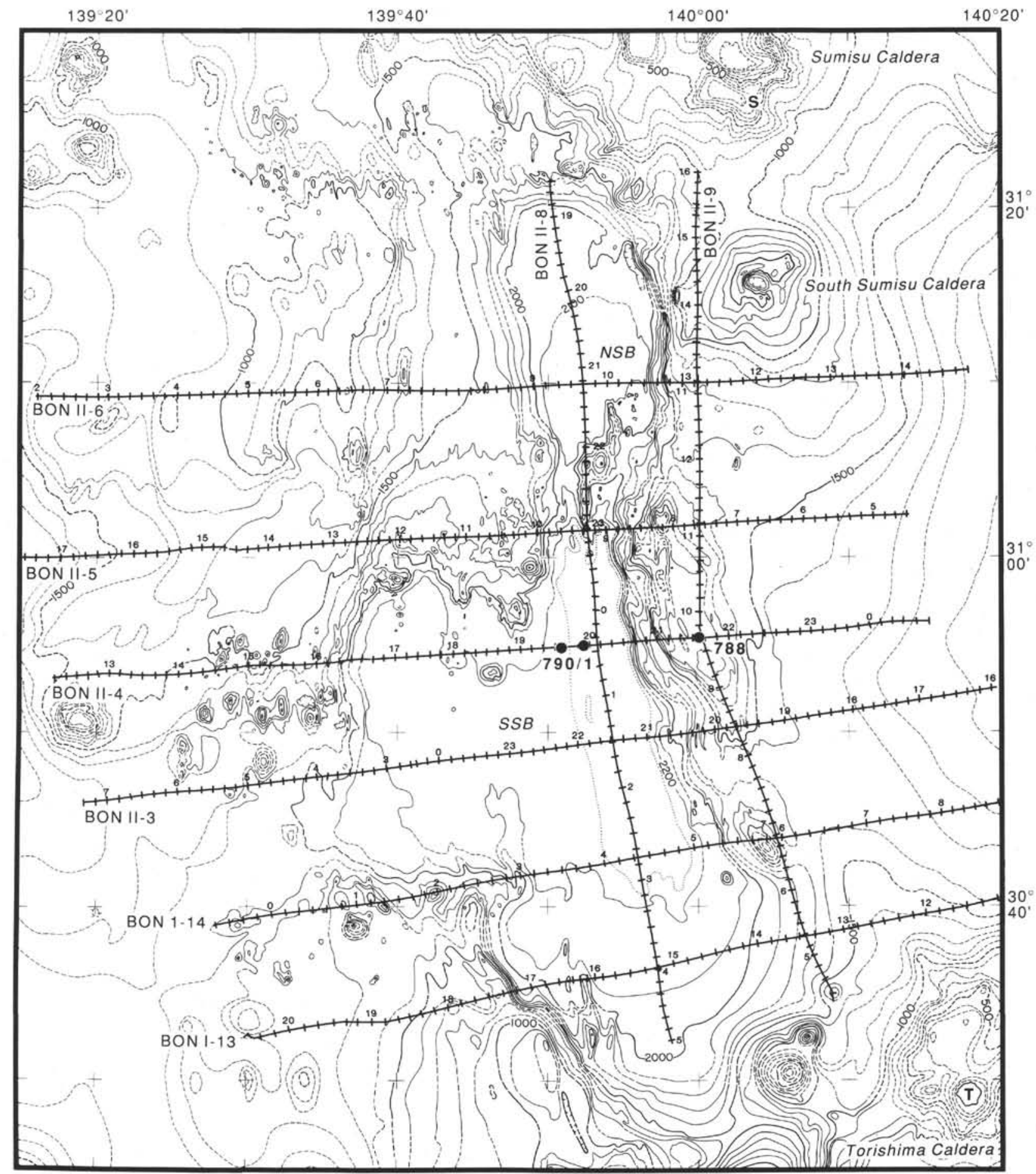

Figure 2. Bathymetric map of the Sumisu Rift showing the location of MCS profiles (Fig. 3; Fred Moore 3505/07). The bathymetry is based on SeaMARC II data (Taylor et al., 1988a), augmented by ship track data and bathymetric charts 6526 and 6527 of the Hydrographic Department of the Japanese Maritime Safety Agency. Tick marks along the ship tracks are at 10-min intervals and labeled every hour. The contour interval is $100 \mathrm{~m}$, except for the 2250-m contour, which is dotted. Dashed contours are either interpolated or not based on SeaMARC II data. The island-arc volcanoes Sumisu Jima and Torishima are labeled $S$ and $T$. NSB = North Sumisu Basin, SSB = South Sumisu Basin. The location of Sites 788, 790, and 791 is shown on line 4. 
North of $30^{\circ} 41^{\prime} \mathrm{N}$, the uplifted footwall of the border faults forms an arc margin typically $1 \mathrm{~km}$ above the sedimented rift basin floor. Three types of rift flank uplifts are observed: (1) large rotated fault blocks bounded by west-dipping faults (profiles 5 and 14, Fig. 3); (2) broad, little-tilted uplifts cut by closer-spaced normal faults dipping to the east and west (profiles 3 and 4, Fig. 3); and (3) relatively flat uplifts (profile 6; Fig. 3).

The first type occurs in two regions of the arc margin, $30^{\circ} 41^{\prime} \mathrm{N}-$ $30^{\circ} 46^{\prime} \mathrm{N}$ (profile 14 , Fig. 3 ) and $31^{\circ} 00^{\prime} \mathrm{N}-31^{\circ} 05^{\prime} \mathrm{N}$ (profile 5, Fig. 3). These rift flank uplifts have two to three fault blocks that dip east at up to $16^{\circ}$, between $60^{\circ}$ to $70^{\circ}$ west-dipping normal faults spaced about $3 \mathrm{~km}$ apart.

Between these two regions of tilted blocks, the arc margin is cut by active, closely spaced, normal faults that dip $65^{\circ}-75^{\circ}$ to both the east and west and result in only minor block tilting (profiles 3 and 4 , Fig. 3). In this region, the faults exhibit an anastomosing and relay pattern (Fig. 5; see also Taylor et al., 1990a, fig. 7). Although this region is cut by numerous small-offset $(20-150 \mathrm{~m})$ faults, two to three large-offset $(300-400 \mathrm{~m})$ faults account for the majority of the total throw down into the rift basin.

The north-central rift segment is bounded by a narrow border fault zone composed of two 400-500-m offset fault zones (Figs. 3 and 5). The arc margin appears quite flat on profile 6 (Fig. 3), in part because of the volcaniclastic apron from South Sumisu Caldera just to the north, and also because of the intrusion near 1400 UTC.

The centers of the footwall uplifts exhibit continuous, parallel, high-amplitude seismic reflections similar to those on the ramping arc margin south of $30^{\circ} 41^{\prime} \mathrm{N}$ (e.g., profiles 3 and 4, Fig. 3). The reflection sequences within the steeper tilted blocks are less well imaged (profiles 5 and 14). All reflections become increasingly disrupted in the border fault zone by the pervasive faulting and possibly by volcanic intrusions similar to those observed during submersible investigations along the eastern rift wall (Taylor et al., 1990a). Well-stratified upper forearc sequences lap onto the eastern side of the footwall uplifts (e.g., 0610 UTC on profile 14, Fig. 3).

At Site 788 (Taylor, Fujioka, et al., 1990) drilling $374 \mathrm{~m}$ into the arc margin at the intersection of profiles 4 and 9 recovered dominantly Pliocene pumiceous gravels and conglomerates (Figs. 7 and 8). An unconformity at $30 \mathrm{~m}$ below seafloor (mbsf) dates the rift flank uplift and presumably the onset of rifting as $>275,000 \mathrm{yr}$ before the present and $<2.35$ $\mathrm{Ma}$. The distinctive stratified pre-rift volcaniclastic sediments are observed on MCS records to $>1200$ mbsf. Benthic foraminifers from $\sim 270 \mathrm{mbsf}$ indicate water depths of $2-3 \mathrm{~km}$ at $\sim 4 \mathrm{Ma}$, which constrains the amount of rift flank uplift at this 1113-mbsl site to 0.6-1.6 km (Kaiho, this volume).

Except for the region where the central transfer zone and northeast volcanic trend intersect the arc margin $\left(31^{\circ} 05^{\prime} \mathrm{N}\right.$ to $31^{\circ} 12^{\prime} \mathrm{N}$, Fig. 5), there is a striking lack of evidence of extrusive volcanism along the volcanic front between the major arc calderas.

\section{PROTO-REMNANT ARC}

The rift basin is bounded to the west by the proto-remnant arc, which rises $300-1500 \mathrm{~m}$ above the sedimented basin floor. It includes a large rotated block in the south and a multiply faulted high in the north. The margin is deepest $(1700-2000 \mathrm{mbsl})$ between $30^{\circ} 400^{\prime} \mathrm{N}$ and $30^{\circ} 48^{\prime} \mathrm{N}$, adjacent to the wide south-central rift segment. The margin of the proto-remnant arc margin is characterized by a reflective sequence of presumed pre-rift volcaniclastic sediments beneath a thin Quaternary cover (Fig. 3).

The normal-faulted rift flank uplift south of $30^{\circ} 42 \mathrm{~N}$ exhibits rotated and tilted fault blocks (Fig. 9) similar in form to those observed in the Bay of Biscay and on other passive margins (de Charpal et al., 1978; Montadert et al., 1979). The MCS data image fault-plane reflections bounding some of these well-stratified blocks. The faults have low near-surface dips $\left(25^{\circ}-50^{\circ}\right)$ and some flatten with depth to $\sim 25^{\circ}$. They do not appear to pass through a region of horizontal reflections at $\sim 4.5 \mathrm{~s}$ ( $2000 \mathrm{mbsf}$, Fig. 9), which may be a zone of detachment. Faults bounding rotated blocks beneath the rift basin are detached at even shallower levels (e.g., Fig. 9). Small-offset west-dipping normal faults occur to the west of the border faults.

North of $30^{\circ} 48^{\prime} \mathrm{N}$, the margin of the proto-remnant arc is flat to dipping gently west (Figs. 3 and 6). The deeper stratified sections are cut by numerous, variably but commonly west-dipping, small-offset normal faults, whereas the surface-breaking faults dip dominantly east (Figs. 3 and 10).

Volcanism on the proto-remnant arc margin is concentrated along extensions of the transfer zones and in the north (Fig. 5). Individual flows and vents are rift elongate and commonly are aligned either along or parallel to faults. Regions interpreted as extrusive volcanism based on sidescan sonar imagery have incoherent reflections on MCS sections (e.g., Fig. 9).

\section{RIFT BASIN}

The locus of maximum sediment thickness (>1 km) and basin subsidence occurs along an inner rift adjacent to the arc margin (Figs. 3 and 6). Typical basin floor depths along the inner rift range from $1600 \mathrm{mbsl}$ in the northern segment to $2100 \mathrm{mbsl}$ in the North Sumisu Basin and $2250 \mathrm{mbsl}$ in the South Sumisu Basin (Fig. 2). In the two northern rift segments, a multiply faulted but less subsided (1300$1900 \mathrm{mbsl}$ ) and thinly sedimented outer rift lies between the inner rift and the border faults to the west (profiles 5 and 6, Fig. 3). In the south-central rift segment, the outer rift has subsided below 2200 mbsl. Below the sediment plain, there is a half graben separated from the inner rift by a structural high (profiles 3 and 4, Fig. 3).

Sites 790 and 791 were drilled on the western margin of the inner-rift half graben in the South Sumisu Basin (Figs. 7 and 8). Drilling at both sites bottomed in vesicular basalt interpreted as a syn-rift deep submarine eruption (Gill et al., 1990; Taylor, Fujioka, et al., 1990), which is underlain at Site 791 by tuffs interpreted as a sequence of island-arc pyroclastic flows. Definite pre-rift sequences were not penetrated. At Site 791, the volcanic intervals correspond to a high-amplitude reflector that is difficult to trace for even a kilometer away from the drill site. The thick, well-stratified pre-rift sequences imaged on the arc margin are obscured beneath the rift basin.

Although the lithostratigraphies are similar at both basin sites, differential subsidence has resulted in a thickening of basin fill toward the eastern margin of the half graben; Site 791 recovered an expanded section from that at Site 790 (Fig. 7). Nannofossil-rich clays and claystones (Unit II) overlie the volcanic rocks. The oldest sediments are $\sim 1.1$ Ma (Taylor, Fujioka, et al., 1990). Correlation of Unit II throughout the rift basin is difficult because of the lack of strong continuous reflectors, complex faulting, and local deposition in small fault-block-bounded depocenters.

Unit II is overlain by thick pumiceous and vitric gravels, sands, and silts (Unit I). The seismic character of Unit I is highly variable throughout the South Sumisu Basin, ranging from transparent or discontinuous to high-amplitude, parallel reflections. In addition, there is a gradual regional transition in seismic facies in Unit I from discontinuous, low-amplitude reflections in the southern South Sumisu Basin toward the north, where higher amplitude, continuous reflections are observed (Fig. 11).

Sedimentation rates (not corrected for compaction) increase from 90 and $300 \mathrm{~mm} / 1000 \mathrm{yr}$ between 0.5 and $1 \mathrm{Ma}$, to 150 and 800 $\mathrm{mm} / 1000 \mathrm{yr}$ between 0.1 and $0.4 \mathrm{Ma}$, to 1.5 and $4 \mathrm{~m} / 1000 \mathrm{yr}$ in the last 0.1 Ma (Unit I) at Sites 790 and 791, respectively (Figs. 7 and 8; Firth and Isiminger-Kelso, this volume; Nishimura et al., this volume). Benthic foraminifers indicate that the sediments were deposited in similar water depths to the present (Kaiho, this volume); we infer that the basin sedimentation rates approximately match the rate of rift basin subsidence.

Syndepositional faulting and subsidence have created reflector sequences that exhibit progressive tilting with depth and commonly onlap earlier syn-rift reflectors or pre-rift blocks. For example, the 


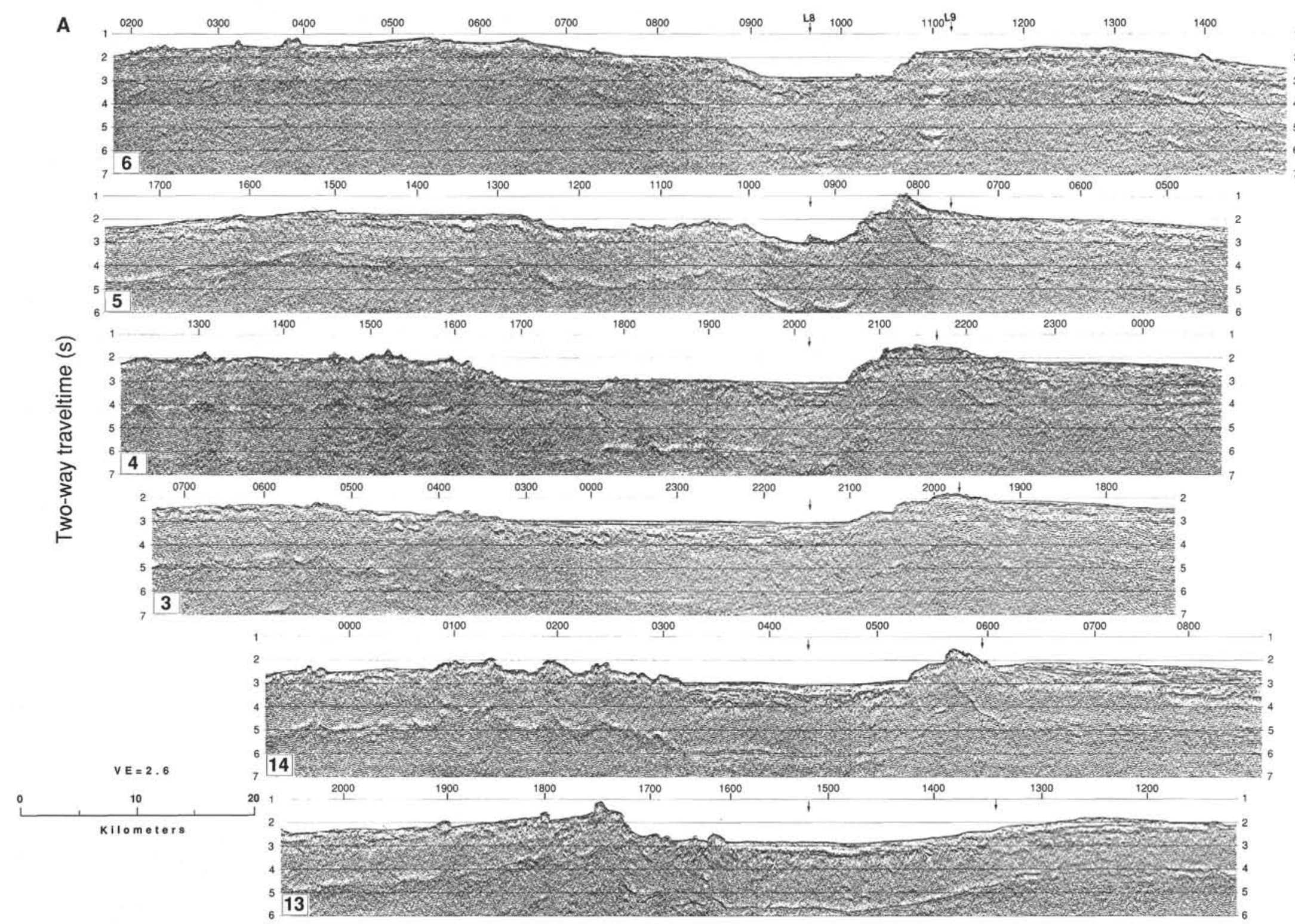

Figure 3. A. Cross-rift, migrated, 96-channel seismic profiles. Large-scale versions of these profiles are published in Taylor et al. (1990b). B. Line drawings of MCS profiles. The location of the profiles is shown in Figure 2. 


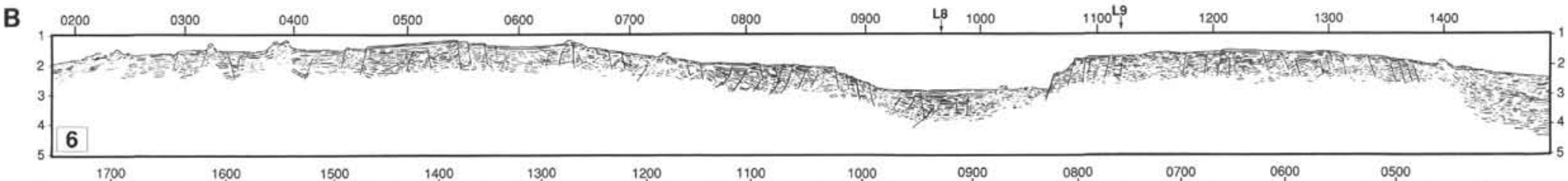

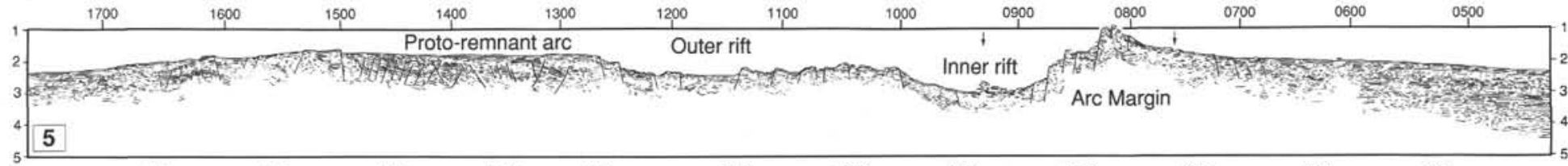

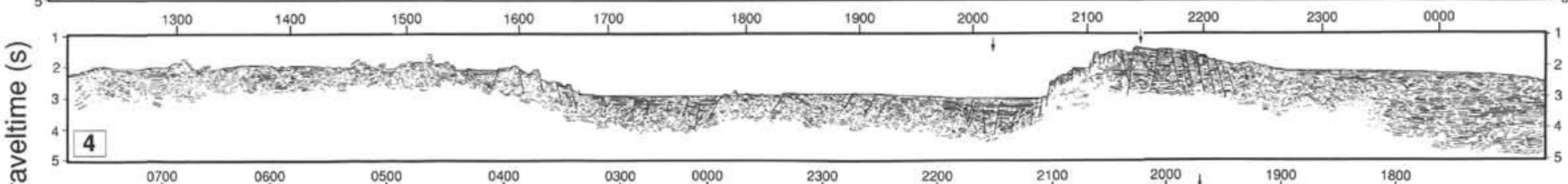

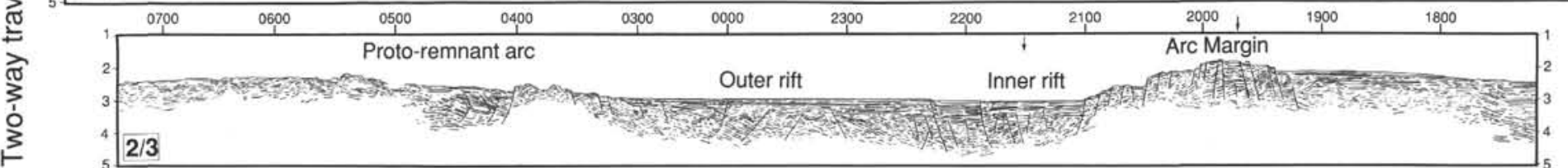
\begin{tabular}{rlllllll}
\hline 0000 & 0100 & 0200 & 0300 & 0400 & 0500 & 0600 & 0700 \\
\hline
\end{tabular} $\sqrt[3]{14}_{14}^{14}$

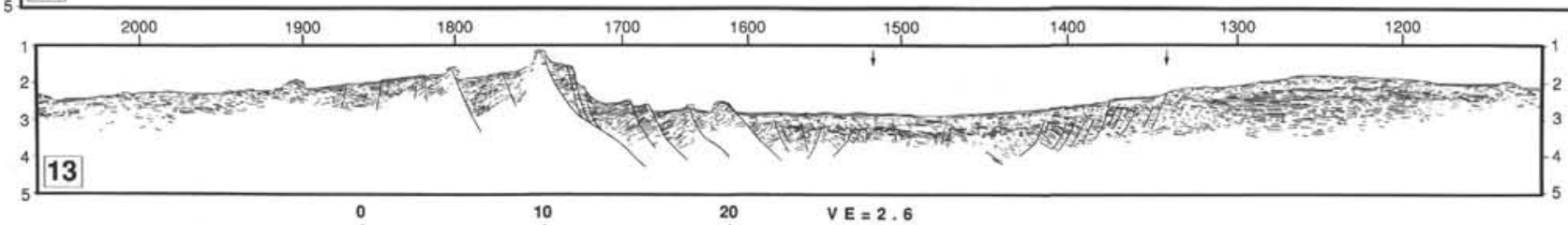
$\frac{10}{1}$ $V E=2.6$

Figure 3 (continued). 


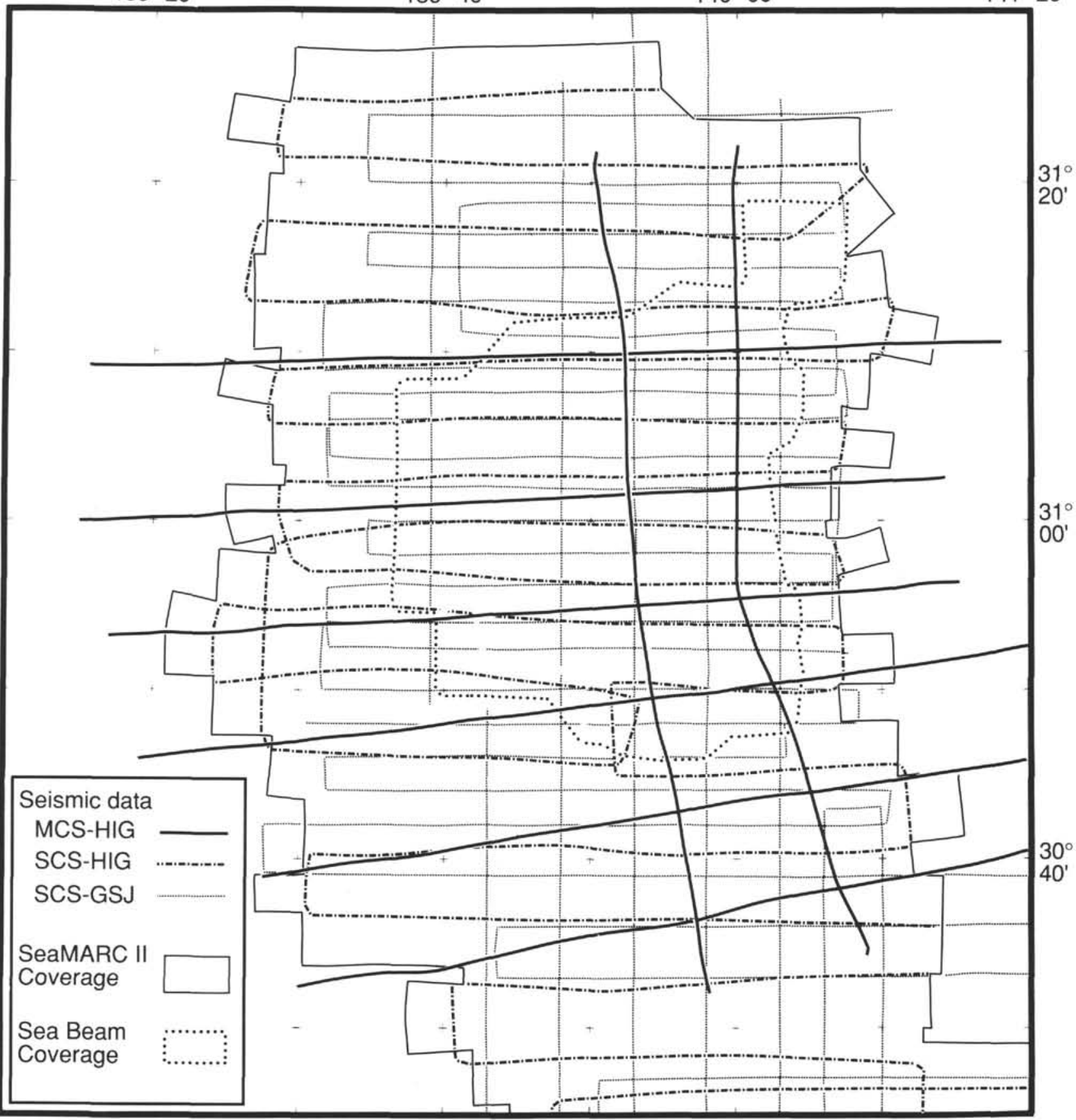

Figure 4. Location map showing data used for the structural (Fig. 5) and stratigraphic interpretations including multichannel (Fred Moore, FM3505 and FM3507: heavy solid lines) and single-channel seismic profiles (Kana Keoki cruise KK840428 Leg 02: dash-dot lines; Hakurei-maru cruises in 1979, 1980, 1984, and 1985: dotted line), SeaMARC II sidescan sonar imagery and bathymetry (Taylor et al., 1988a, 1988b: solid outline), and SeaBeam bathymetry (Taylor et al., 1990a: dotted outline).

bedding is subhorizontal at Site 790 , but at Site 791 the dip increases gradually to $15^{\circ}-20^{\circ}$ near $600 \mathrm{mbsf}$ and $45^{\circ}$ by $800 \mathrm{mbsf}$ (Taylor, Fujioka, et al., 1990). Figure 12 shows an example where the variably tilted and faulted deeper horizons are cut by currently active east-dipping faults, thereby reversing the direction of tilting of the western two-thirds of the section. The two to three east-dipping faults that bound the western side of the inner rift in the South Sumisu Basin are extremely fast slipping, as they offset, with a cumulative throw of $55-70 \mathrm{~m}$, the rapidly sedimented $(4 \mathrm{~m} / 1000 \mathrm{yr})$ basin floor.
The pattern of sediment accumulation, basin subsidence, and volcanic intrusions for the last $67,000 \mathrm{yr}$ in the South Sumisu Basin is shown in Figure 13. This isopach map was constructed by correlating our MCS data with recovered core material from Sites 790 and 791 using shipboard physical-properties velocities to convert depth (mbsf) into two-way traveltime. Next, a distinctive reflector that corresponds to $67,000 \mathrm{yr}$ before the present was mapped throughout the South Sumisu Basin. Correlation of deeper reflectors throughout the basin is problematic because of pervasive faulting. Although the 


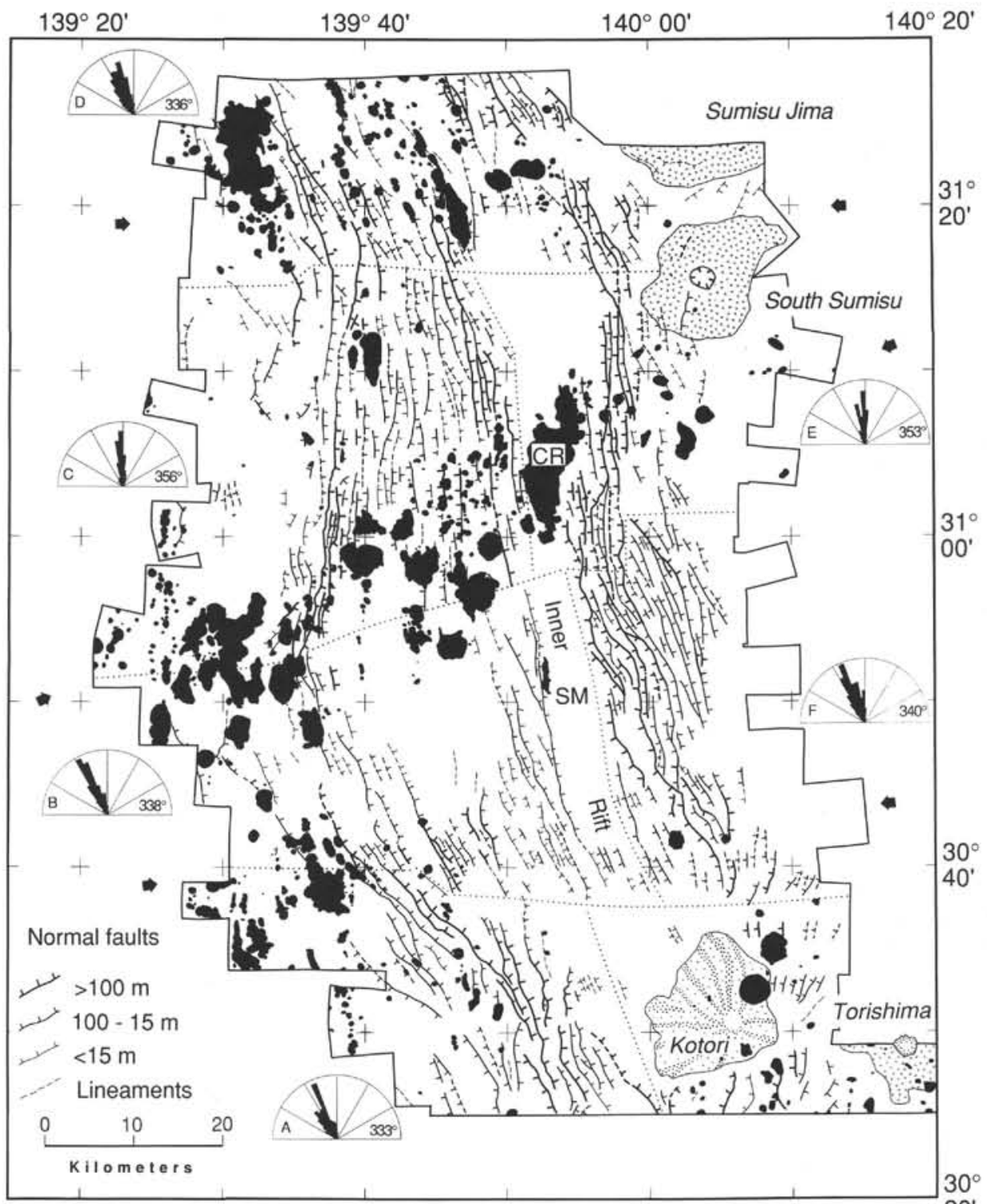

Figure 5. Structural map of the Sumisu Rift. The location of data used to constrain interpretations is shown in Figure 4. Dark shaded areas are extrusive volcanic rocks (from Taylor et al., 1990a). The active arc calderas are Sumisu, South Sumisu, and Torishima; Kotori is a pyroclastic cone. $\mathrm{CR}=$ Central Ridge, $\mathrm{SM}=$ Shadow Mountain. Polar histograms (cumulative fault length vs. azimuth) and average fault strike are shown for the regions outlined by dots. Arrows point to the three transfer zones.

distinct, high-amplitude, well-layered, pre-rift sequences observed on the rift margins presumably underlie the rift basin, the similarity of the facies to the syn-rift fill (Fig. 8), together with overprinting by faulting and volcanism, prevents clear distinction of the two sequences and the preparation of depth to "basement" (pre-rift) maps.

In the upper Quaternary, the maximum sediment thickness, and basin subsidence, is located within the inner rift where the 67,000-yr isopach is more than $0.5 \mathrm{~s}$ of two-way traveltime $(\sim 400 \mathrm{~m})$. This implies that sedimentation rates within the inner rift are as high as 6 $\mathrm{m} / 1000 \mathrm{yr}$. Another rift-elongate, fault-controlled depocenter is observed in the outer rift and is outlined by the 0.2-s isopach (Fig. 13).

Syn-rift sediments are disrupted by volcanic intrusions that occur along rift faults and rift-parallel trends (Figs. 5 and 13). Shadow Mountain, a 50-75-m-high, 3-km-long fissure ridge (near $30^{\circ} 51^{\prime} \mathrm{N}, 139^{\circ} 53^{\prime} \mathrm{E}$ ), was emplaced along the fault that bounds the western side of the inner rift. A linear series of small intrusions that penetrate the seafloor, near $139^{\circ} 40^{\prime} \mathrm{E}$ between $30^{\circ} 50 \mathrm{~N}$ and $30^{\circ} 57 \mathrm{~N}$, parallels the local rift fault trends (Figs. 5 and 13). The syn-rift volcanic rocks are dominantly basalts of backarc basin composition, little influenced by arc components (Fryer et al., 1990; Gill et al., 1990; Hochstaedter et al., 1990).

\section{PRE-RIFT STRUCTURES}

Unlike continents, where cratons or thrust-thickened crust can provide complex structural anisotropy, island arcs have a more twodimensional rheology. As in other arcs, elevated heat flow and thicker crust are associated with the Izu-Bonin volcanic line (Hotta, 1970; Honza and Tamaki, 1985). Two-ship refraction profiles suggest that the depth to Moho is about $20 \mathrm{~km}$ beneath the volcanic front at $28^{\circ}-32^{\circ} \mathrm{N}$, compared to $15 \mathrm{~km}$ beneath the outer forearc high and 12 $\mathrm{km}$ beneath the Shikoku Basin (Hotta, 1970; Japanese DELP Research Group on Back-arc Basins, 1989). Thicker crust and higher 


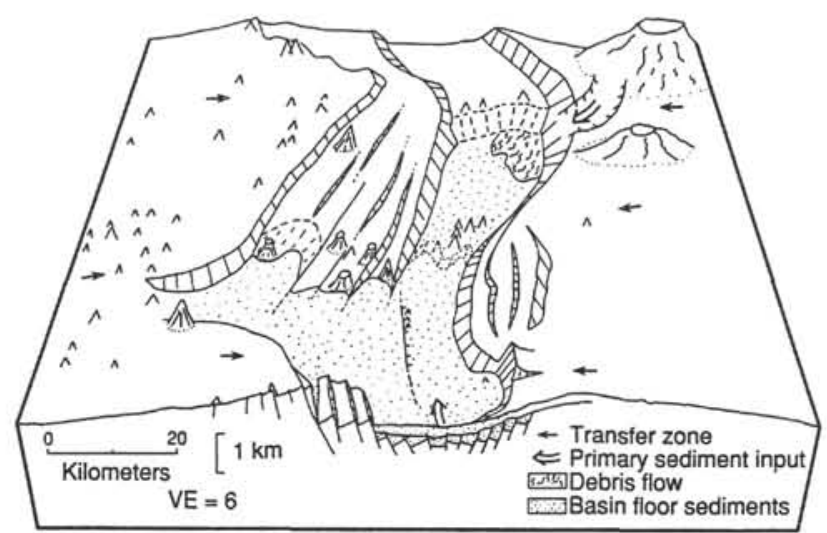

Figure 6. Perspective block diagram of Sumisu Rift, viewed from an elevation of $65^{\circ}$, looking $345^{\circ} . \mathrm{VE}=$ vertical exaggeration.

heat flow have been shown to weaken the lithosphere (Vink et al., 1984; Steckler and ten Brink, 1986; Kuznir and Park, 1987). We therefore infer that the line of arc volcanoes creates a linear zone of lithospheric weakness that controls the location of rifting. This implies that rifting can occur on either side of the active arc, as is observed globally (Taylor and Karner, 1983). In the Izu-Bonin Arc, the majority of the rifts are backarc, but at $29^{\circ} \mathrm{N}$ one of the rifts is on the forearc side of the volcanic front (Fig. 1).

The preceding arguments would suggest that arc rifting should initiate adjacent to the volcanoes. In fact, just the opposite is observed (Fig. 1). For example, structural highs and submarine volcanoes adjacent to Sumisu Jima, Torishima, and Sofu Gan bound the ends of the Sumisu and Torishima rifts. Likewise, the rift basins farther north narrow adjacent to Myojin Sho and Aoga Shima (Fig. 1). The rifts are better developed between, rather than adjacent to, the arc volcanoes. We suggest that this may result from arc magmatism accommodating some of the extension, with intrusions rather than faulting taking up the strain adjacent to the arc volcanoes. The large submarine volcano at $28.3^{\circ} \mathrm{N}$ may have suppressed or overprinted rift basin development between the Sofu Gan and Nishinoshima rifts (Fig. 1).

As outlined previously, the Izu-Bonin Arc was stretched in the Oligocene, prior to the 25-15-Ma backarc spreading in the Shikoku Basin. There are major relict north-northeast- and north-northwesttrending half grabens in the forearc and the backarc, many of which are still recognizable in the bathymetry (Fig. 1). Northeast- to easttrending chains of seamounts are prominent to the west of the arc; some may have been erupted along Shikoku Basin fracture zones. Whether any of these cross-arc features have influenced present rift structures, such as the similarly trending transfer zones, is equivocal. In the case of Sumisu Rift, however, there are no obvious correlations of syn-rift and pre-rift structures.

\section{FAULT PATTERN}

Normal faulting in the Sumisu Rift exhibits a zigzag pattern in plan view (Murakami, 1988; Brown and Taylor, 1988; Taylor et al., $1990 \mathrm{a}$ ), with dominant $\mathrm{N} 23^{\circ} \pm 10^{\circ} \mathrm{W}$ and $\mathrm{N} 5^{\circ} \pm 10^{\circ} \mathrm{W}$ strikes (Fig. 5). Transfer zones occur where the rift segments change trend $\left(\sim 31^{\circ} 18^{\prime} \mathrm{N}\right.$ and $\left.31^{\circ} \mathrm{N}\right)$ or change asymmetry $\left(\sim 30^{\circ} 40^{\prime} \mathrm{N}\right)$. The differential stretching and uplift/subsidence across the transfer zones is accommodated by relay zones of interdigitating, rift-parallel normal faults, and some cross-rift volcanism, rather than by rift-oblique strike-slip faults (Taylor et al., 1990a). The zigzag fault pattern is evidenced at all scales, along individual faults as well as between rift segments (Fig. 5; see fig. 7 in Taylor et al., 1990a). Faults with both trends dip east and west, forming a geometry with orthorhombic symmetry. This fault style is consistent with recent theoretical (Reches, 1983; Krantz, 1988) and empirical (Oertel, 1965; Reches and Dieterich, 1983) models of fault formation in three-dimensional strain fields. These models predict that the maximum strain direction is perpendicular to the bisector of the acute angle between the two fault trends. In the Sumisu case, this analysis suggests an extension direction of ${\mathrm{N} 76^{\circ}}^{\circ}$ $\pm 10^{\circ} \mathrm{E}$, nearly orthogonal to the trend of the volcanic $\operatorname{arc}\left(\mathrm{N} 10^{\circ} \mathrm{W}\right)$.

Note that, although the border fault zones are curvilinear, they have convex as well as concave dip slopes (Figs. 5 and 6). Rosendahl (1987), although acknowledging evidence for an orthorhombic fault geometry in the East African rifts, argued that the fundamental unit of rift architecture is a concave half graben, several of which may be linked along strike by oblique transfer zones. Convex, as well as concave, zigzag border fault systems are well documented for the East African rifts however (e.g., between the Moba and Marungu basins of the Tanganyika Rift; Ebinger, 1989b), and we do not see strong evidence for Rosendahl's preferred pattern in the Izu-Bonin rifts.

\section{STRUCTURAL EVOLUTION}

Our minimum estimates of extension across Sumisu Rift using measurements of fault offsets on MCS sections range from 2 to $5 \mathrm{~km}$, with the higher values for the southern rift segment, where fault dips are shallower. Cumulative throws across the border fault zones range from 2 to $2.5 \mathrm{~km}$. Together with the young age of the system ( 2 m.y.) and the accelerating subsidence rates (both documented by Leg 126

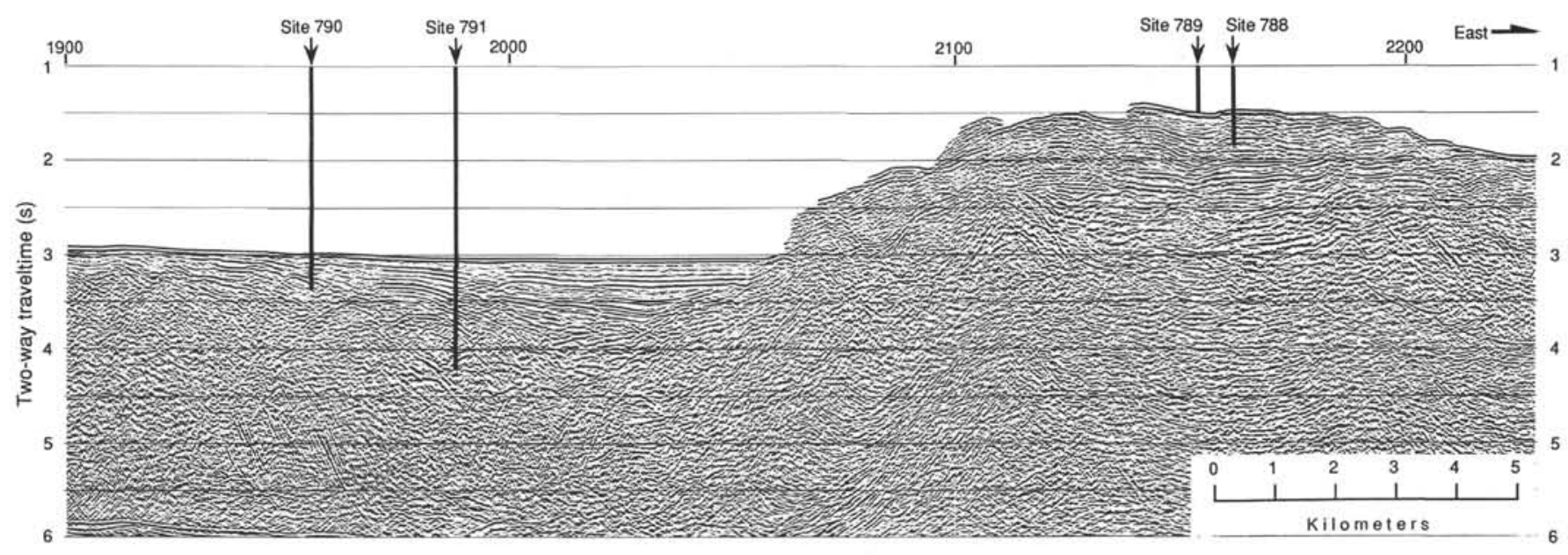

Figure 7. Seismic profile 4 showing the location of Leg 126 drill sites in the rift and on the arc margin. 
Site 790
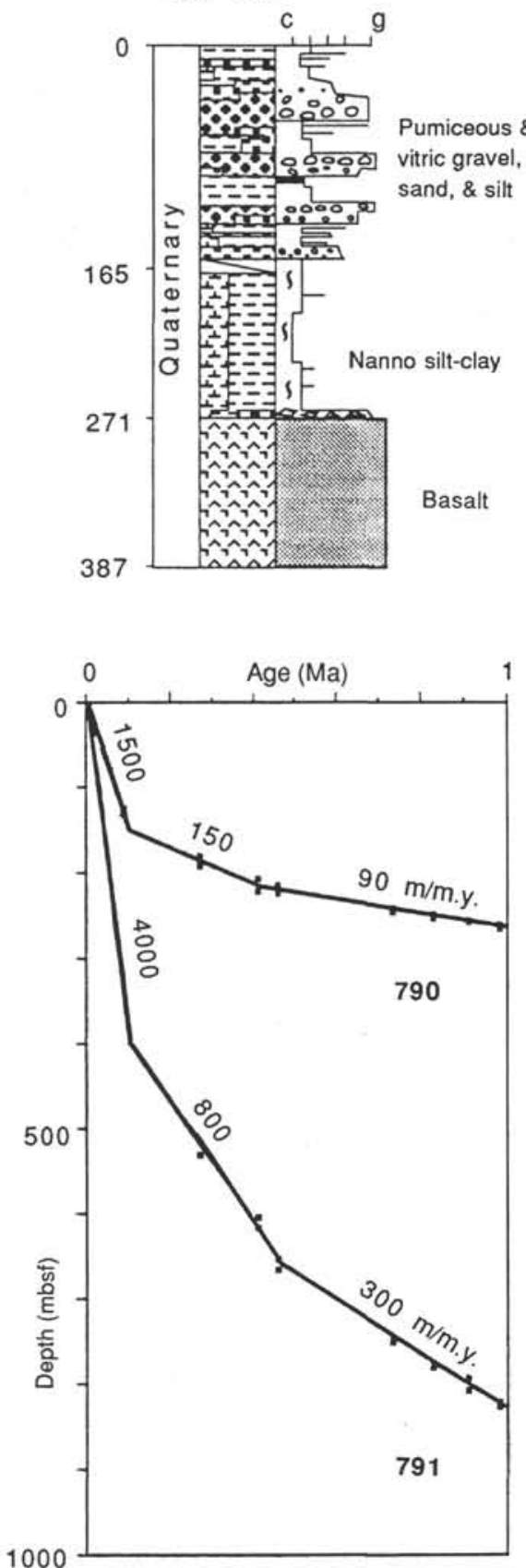

Site 791

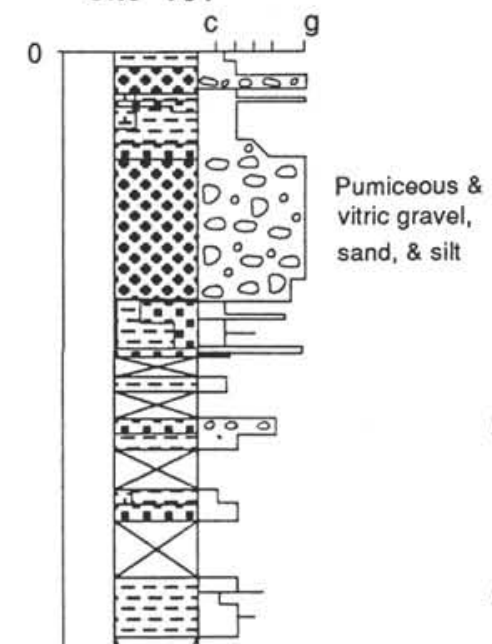

428

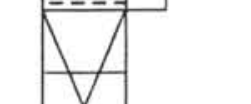

374
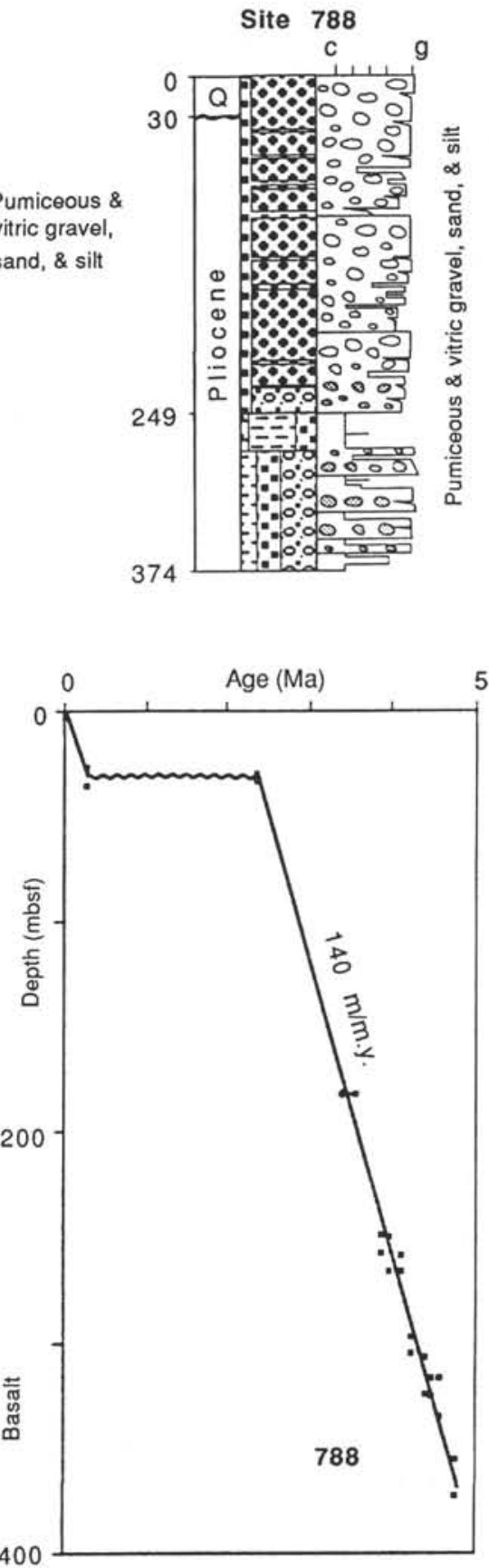

1145

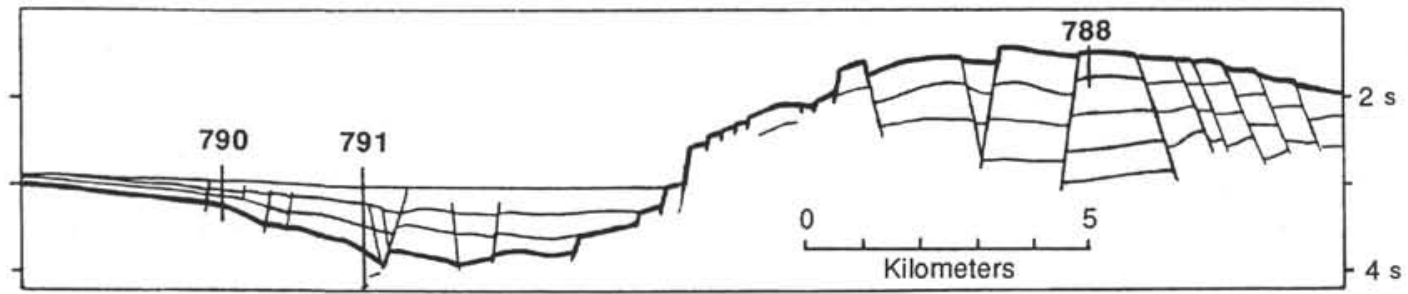

Figure 8. Stratigraphy of Sites 788, 790, and 791 including lithologic columns, age vs. depth diagrams, and a simplified cross-section (Taylor, Fujioka, et al., 1990). The age vs. depth diagrams are modified using data from Firth and Isiminger-Kelso (this volume) and Nishimura et al. (this volume). The average sedimentation rate for each age-depth segment is labeled. 

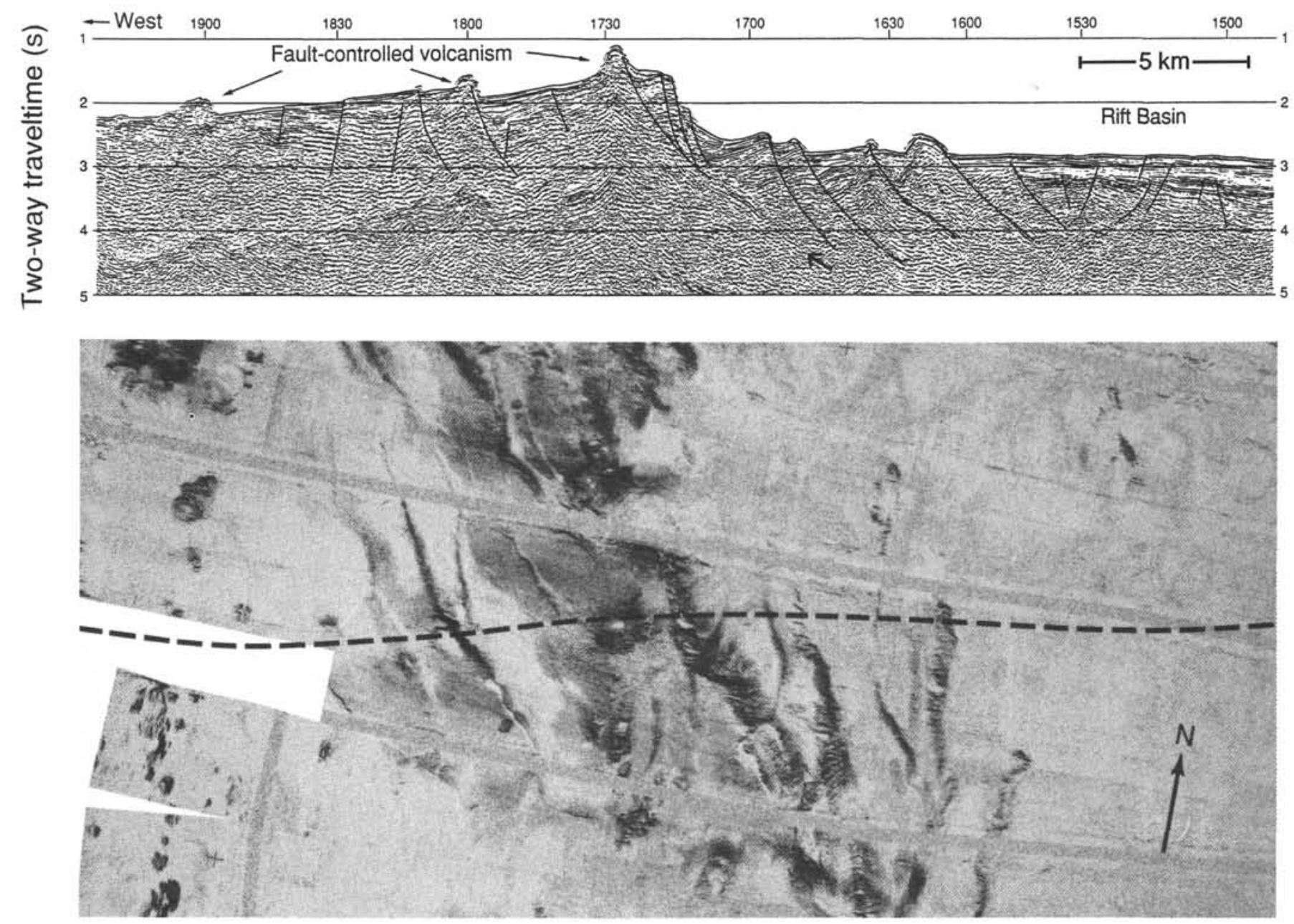

Figure 9. MCS seismic profile 13 (top) and SeaMARC II sidescan sonar imagery (bottom) across the southwestern rift border fault zone. The dashed line on the sidescan data locates the seismic profile. The sidescan data display strong acoustic returns (e.g., fault scarps or extrusive volcanic rocks) as dark and weak acoustic returns (e.g., sediments) as light. In addition to routine processing (through migration), the seismic profile was corrected for the effects of dip using prestack dip-moveout and is displayed at a seafloor vertical exaggeration of 2.6 . The border fault dips shoal from $25^{\circ}$ to $50^{\circ}$ near the surface to $\sim 25^{\circ}$ at $4 \mathrm{~s}$. Fault plane reflections are observed from several of the shallow-dip faults (e.g., arrow on MCS profile).

drilling), these data indicate that Sumisu Rift is still in the early syn-rift stage of its development. Nevertheless, an evolution in structural style is already apparent from the seismic stratigraphy (Figs. 3, $7,9,10$, and 12).

Figure 14 shows our schematic interpretation of the structural development of Sumisu Rift, including some of the along-strike variations. Sections 1A and 1B (Fig. 14) show a two-stage development of the northern Sumisu Rift segments, based on our interpretations of profiles 5 and 6 (Figs. 3 and 10). Sections 2 and 3 (Fig. 13) show the structural variations seen in the south-central (profiles 3 and 4, Fig. 3) and southern (profile 13, Fig. 3) rift segments. The first stage, which follows an even earlier sag phase, is a half graben with a structural rollover facing a large-offset border fault zone. The hanging-wall faults are typically synthetic to the border faults (Fig. 14 , sections $1 \mathrm{~A}$ and 2 ) though not always (note the sag and the antithetic faults in section 3 ). The zigzag fault pattern and the alternating rift asymmetry (Figs. 5 and 6) would already exist at this stage. This fault geometry is similar to that observed early in the development of continental rifts such as in East Africa (e.g., Rosendahl, 1987; Ebinger, 1989b).

The present, "full graben," stage is heralded by the initiation of dominantly antithetic faulting in the hanging wall that serves to concentrate subsidence in an inner rift along the arc side (Fig. 14, section 1B). Similar focusing of rift subsidence is seen in continental rifts (Ebinger, 1989b), but in contrast to the East African rifts (Ebinger, 1989a), the hanging-wall collapse is not necessarily the result of the propagation of border faults from the adjacent rift segments. Rather, the border faults and hanging-wall faults of adjacent rift segments may be discontinuous across transfer zones, as is the case across the central and southern Sumisu Rift transfer zones (Fig. 5 and 6). Backarc magmatism occurs in the rift and on the proto-remnant arc margin during both stages. Jostling (seesaw motion) of rift basin fault blocks, the development of an outer-rift graben, and basin widening by footwall collapse may accompany the second stage (Fig. 14, section 2).

The rift flanks are flexurally uplifted as the hanging walls subside; the footwall rebounds isostatically to compensate for the mechanical unloading (Weissel and Karner, 1989). The benthic foraminifer data indicate 1.1 $\pm 0.5 \mathrm{~km}$ of flank uplift at Site 788 during the $1.1 \mathrm{~km}$ of basin subsidence (volcanic and sedimentary filling at near-constant water depths) at Site 791 (Kaiho, this volume). Unpublished isostatic modeling by the second author in J. K. Weissel and G. D. Karner's laboratory shows that bathymetry and gravity profiles across the Sumisu and Torishima rifts can be fit well by models with small amounts of extension $(<5 \mathrm{~km})$ on low-angle $\left(\sim 25^{\circ}\right)$ normal faults offsetting a rheologically weak lithosphere (effective elastic thickness $T_{\mathrm{e}} \sim 3 \mathrm{~km}$ ) of arc crustal thickness (15-20 km). Weissel and 


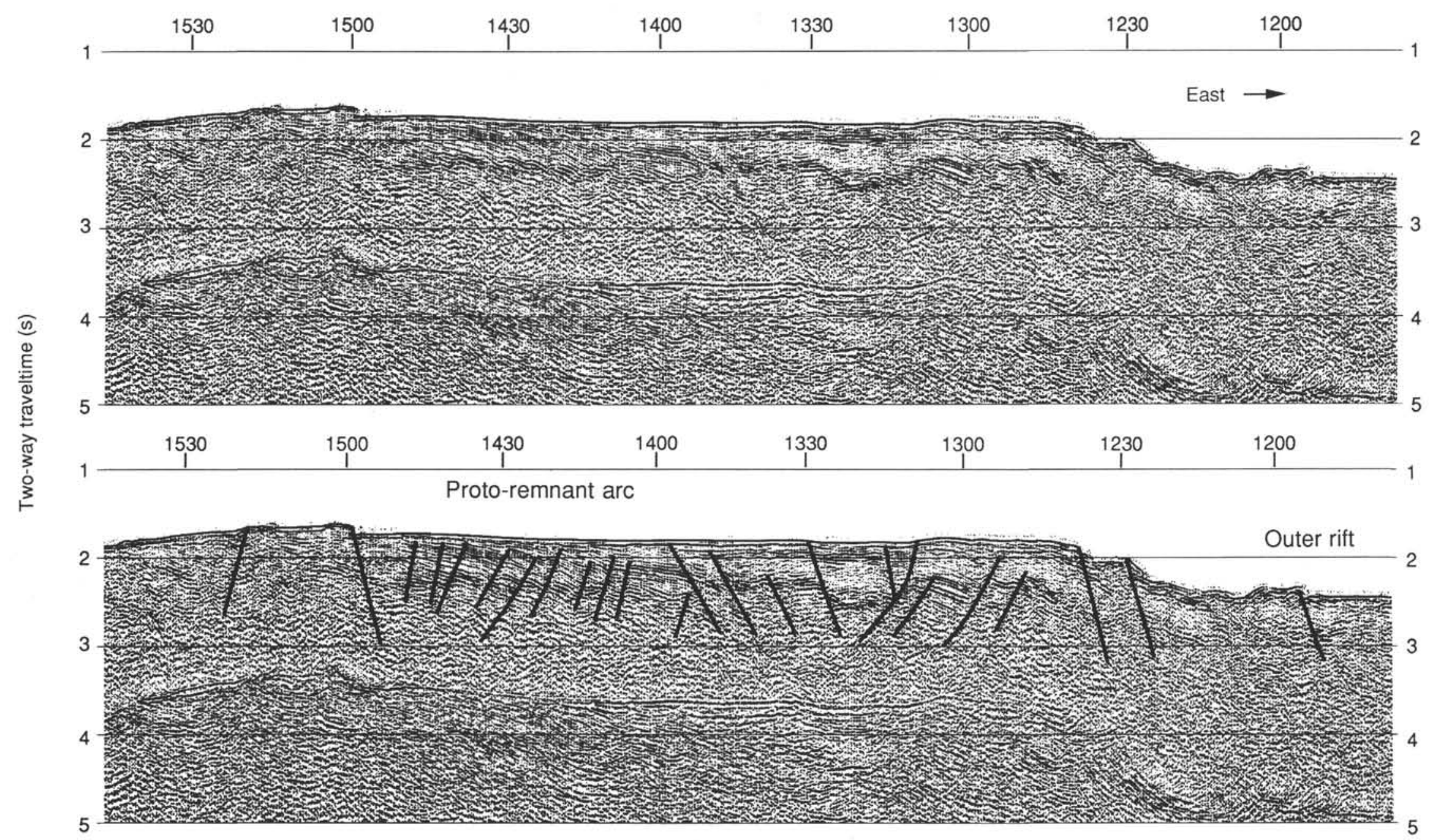

Figure 10. A section of seismic profile 5 (vertical exaggeration $=6$ ) illustrating fault superposition on the proto-remnant arc margin. The majority of the faults that offset the seafloor dip east whereas many of the early faults dip west, synthetic to the border faults bounding the rift to the east. 


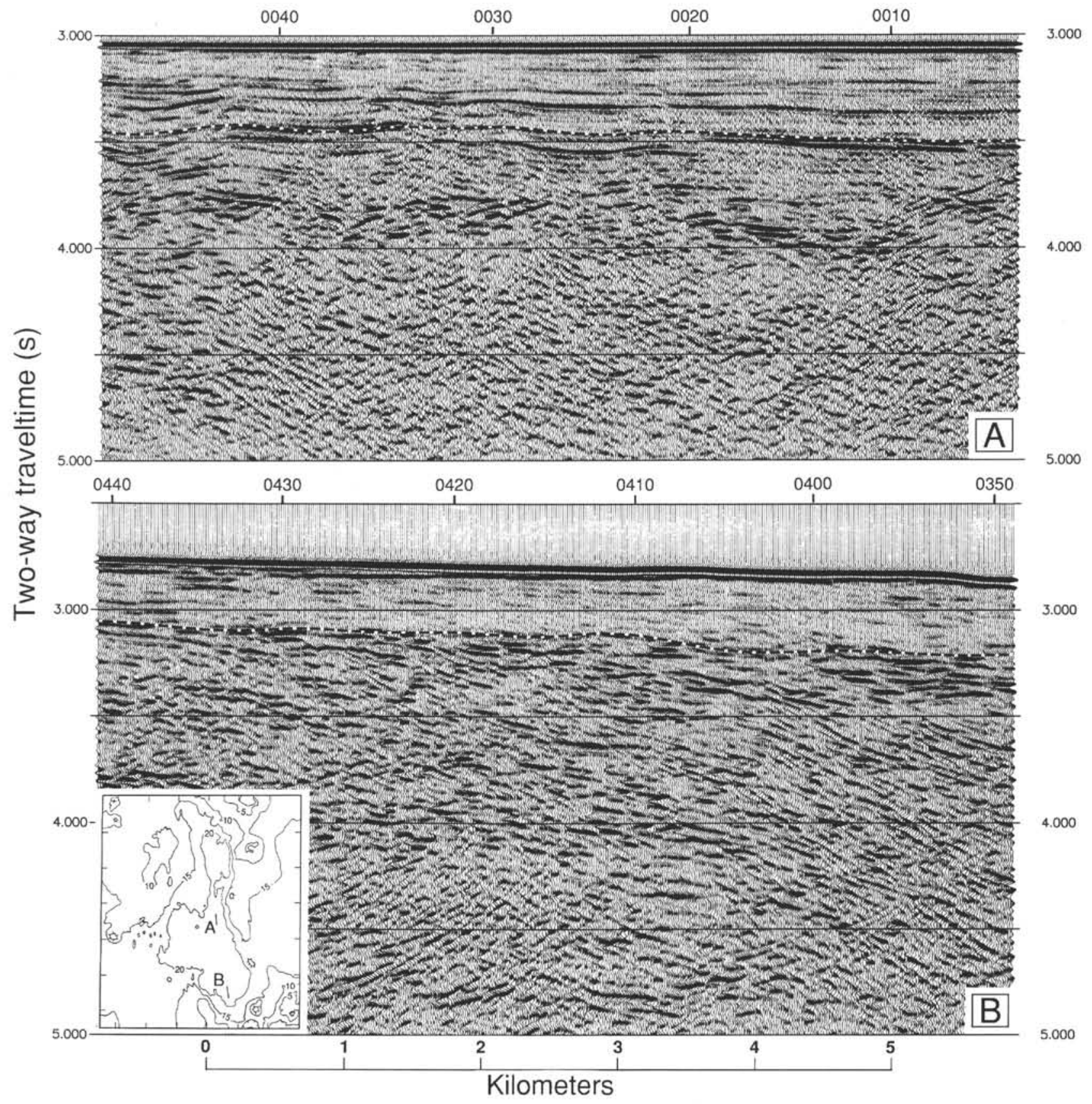

Figure 11. Two segments of MCS seismic profile 8 (vertical exaggeration $=2.1$ ) from the South Sumisu Basin. We infer that the primary sediment input into the South Sumisu Basin is from the Torishima Caldera to the south, based on the northward gradation from discontinuous to continuous reflection character. The southern part of the basin is characterized by more discontinuous reflections (B) than the northern part (A). Both the upper, low-amplitude and the lower, high-amplitude reflections become more continuous toward the north as the distance from the inferred sedimentary source increases. The dotted line locates the reflector mapped in Figure 13.

thickness $T_{\mathrm{e}} \sim 3 \mathrm{~km}$ ) of arc crustal thickness (15-20 km). Weissel and Karner (1989) published a similar result for the Coriolis Trough, the active backarc rift of the New Hebrides arc. Such modeling fits the data particularly well for gently sloping footwall flanks, such as observed on profiles 5 and 13 (Fig. 3), but does not attempt to match the much shorter wavelength structures resulting from footwall and hanging-wall collapse. Many of the latter structures, such as the rotated block at 0600 UTC on profile 14 (Fig. 3) and the region of Site 791 (discussed previously), are detached only a few kilometers below the seafloor.
Whether or not the border faults offset the entire crust and lithosphere remains speculative as the MCS data do not image the faults for more than a few kilometers beneath the seafloor. The heave and the dips of the border faults as well as the rollover geometry of the rift basin are substantially different in sections $1 \mathrm{~B}$ and 3 of Figure 14. which approximately correspond to seismic profiles 6 and 13 (Fig. 3). Area balance depth-to-detachment estimates (Gibbs, 1984) indicate $10-15-\mathrm{km}$ vs. $5-10-\mathrm{km}$ detachment, respectively, but such estimates make several unconstrained assumptions. Thus, although the 


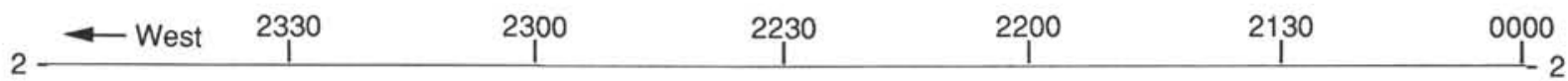
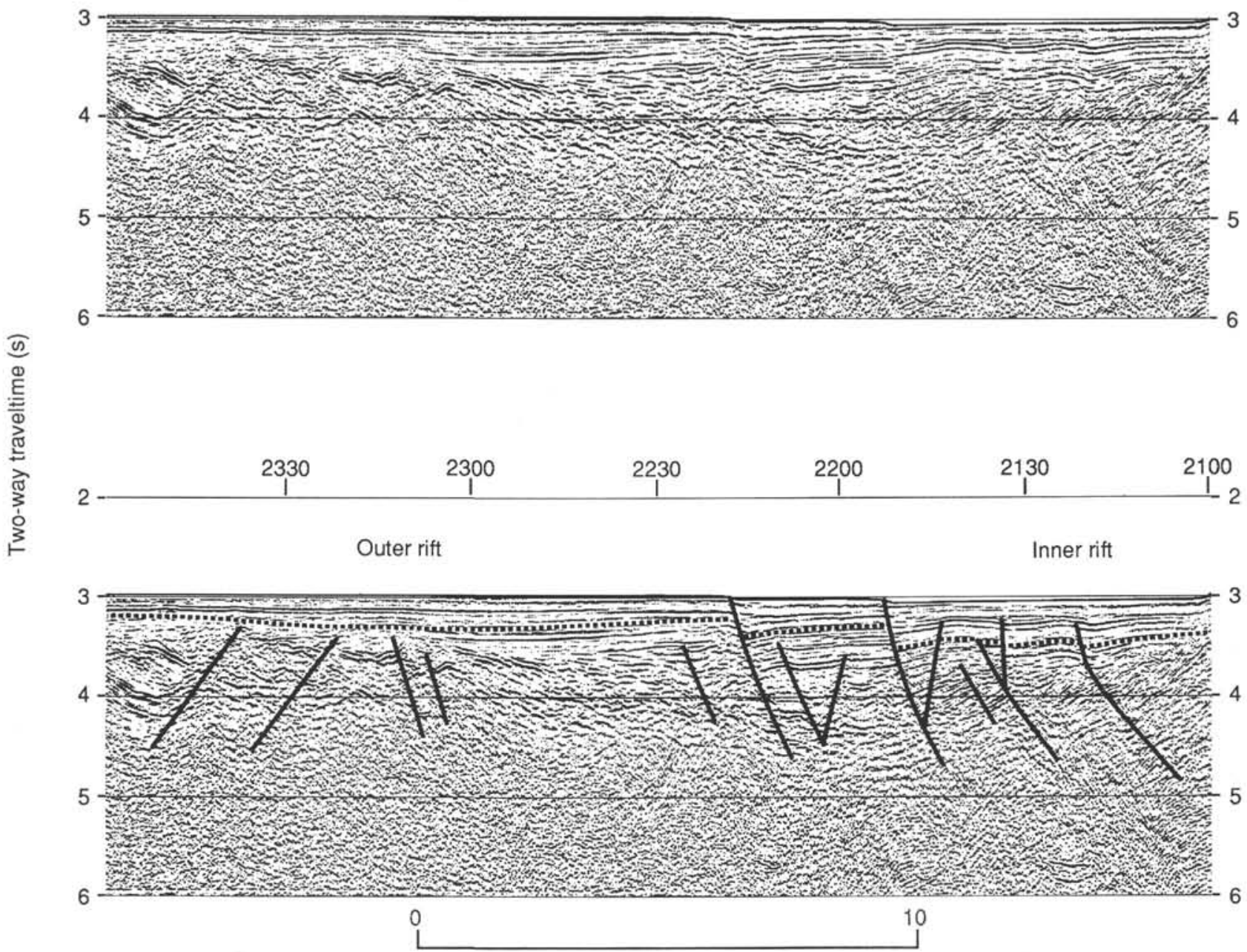

Kilometers

Figure 12. Section of seismic profile 3 (vertical exaggeration $=2.6$ ) in the rift basin illustrating the reversal of stratigraphic tilting by the late-stage, inner-rift-bounding faults. The dotted line locates the reflector mapped in Figure 13.

geometry of the northern rift segments is consistent with high-angle faults substantially cutting through the crust-whereas in the southern rift segment the faults may be detached at middle to upper crustal levels-these are speculations, not conclusions.

\section{SEDIMENTATION PROCESSES}

The eruptive pattern of the adjacent arc volcanoes is the dominant control on sediment input to the rift. Episodic eruptions have supplied a series of coarse pumiceous deposits that are inferred to have been deposited geologically instantaneously by air fall and submarine mass flows (Nishimura et al., this volume). A dramatic increase in explosive arc volcanism since $\sim 102,000 \mathrm{yr}$ before the present resulted in the extremely high observed basin sedimentation rates (Fig. 8) of up to $6 \mathrm{~m} / 1000 \mathrm{yr}$ in the inner rift. Before and between these catastrophic events, nannofossil clays and fine-grained volcanic ash, input by pelagic rain and air falls from more distant volcanoes, produced much slower sedimentation rates. Pre-rift sediments drilled on the arc margin (Site 788:
Fig. 8; Taylor, Fujioka, et al., 1990) document a similar episodic sedimentation pattern and emphasize the strong control of the arc volcanoes on arc margin and rift basin sedimentation.

Most of the sediments are input by the arc volcanoes into the northern and southern ends of Sumisu Rift. Sumisu and South Sumisu calderas feed sediment into the northern end of North Sumisu Basin. A valley extends down the flank of Sumisu Jima directly into the basin (Fig. 2). A debris-flow deposit occurs on the basin floor at the bottom of this valley (Fig. 15). The deposit covers $>20 \mathrm{~km}^{2}$, rises over $100 \mathrm{~m}$ above the basin floor, and exhibits the disrupted internal reflections typical of debris flows. A southward transition from the disrupted reflections in the vicinity of the debris flow to more continuous and higher amplitude reflections provides additional evidence for sediment input from the north and southward transport.

Torishima Caldera and Kotori Volcano feed sediment directly into the South Sumisu Basin and have been the primary source of its sediment. The northward transition from discontinuous, low-amplitude reflections to continuous, higher amplitude reflections (Fig. 11) 


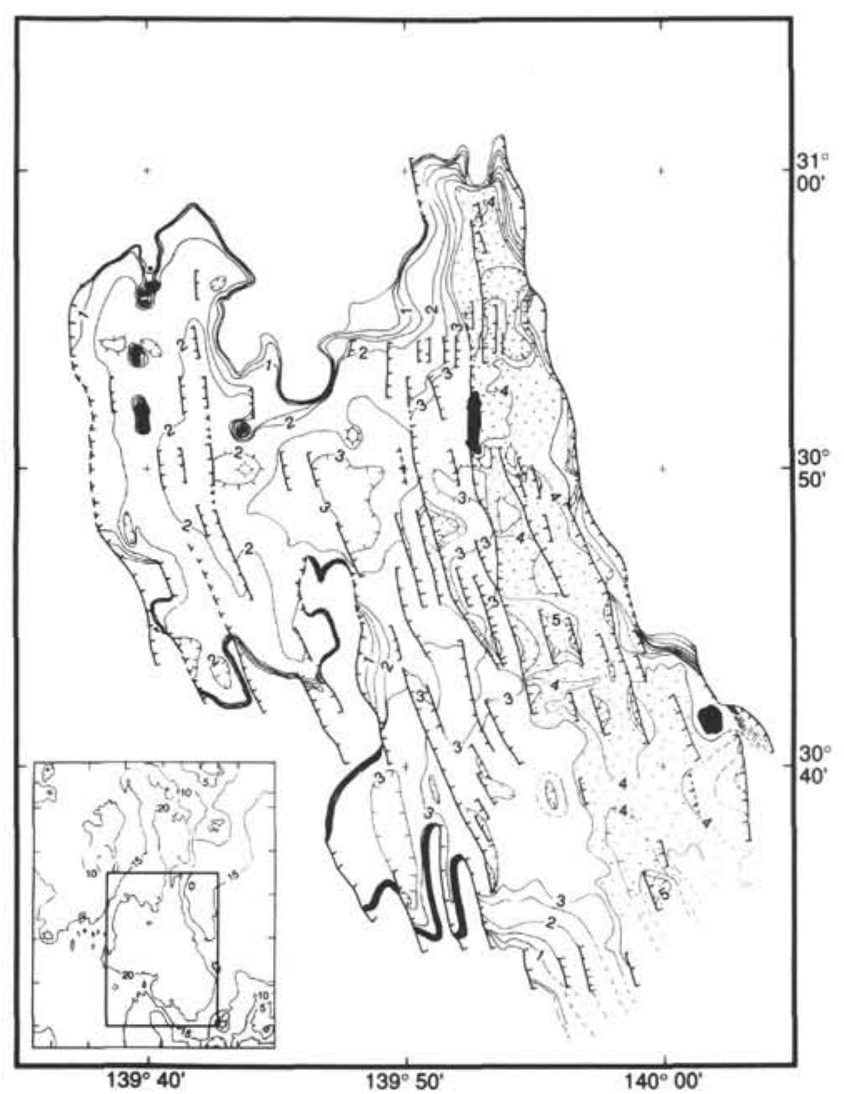

Figure 13. South Sumisu Basin isopach map of a reflector (see Figs. 11 and 12) corresponding to $67,000 \mathrm{yr}$ before the present. Contours are labeled in tenths of seconds of two-way traveltime. The contour interval is $0.05 \mathrm{~s}$; volcanic extrusions are black. The stipple pattern identifies regions with sediment thicknesses $>0.35 \mathrm{~s}$, primarily within the inner rift. The box within the inset bathymetric map shows the location of the isopach map.

is interpreted to represent increasing transport distance from the arc volcanic source. A similar transition in the $3.5-\mathrm{kHz}$ seismic-reflection character, as well as the presence of hummocky seafloor topography produced by slumps in the southern portion of South Sumisu Basin (Brown and Taylor, 1988; Nishimura and Murakami, 1988), supports this interpretation.

The presence of an unconformity between the thin ( $30 \mathrm{~m})$ Quaternary section and the Pliocene pumice at Site 788 (Fig. 8) indicates that extensive erosion of the arc margin has occurred. However, any evidence for lateral sediment input by large-scale slumping along the border faults is presently overwhelmed by the immense volcanic input at the ends of the rift. Only small sediment aprons occur at the base of the steep border fault scarps. One small, thin $(\sim 25 \mathrm{~m})$ sediment fan occurs downslope of a fault-controlled embayment in the arc margin near $31^{\circ} 51 \mathrm{~N}$ and extends about $2 \mathrm{~km}$ onto the sedimented rift basin floor (Fig. 16).

Rift basin depocenters are largely fault controlled, both at the large scale of differential rift segment subsidence and at the scale of small tilt blocks (Fig. 13). Concentration of subsidence in the inner rift, caused by antithetic faulting during the "full graben" stage of rift evolution, has resulted in a rift-elongate depocenter at the foot of the arc margin. Outer rift subsidence in the south central rift segment has localized a parallel depocenter farther west. Volcanism and differential subsidence across the central transfer zone have acted as a partial barrier to sediment transport between the North Sumisu Basin and the South Sumisu Basin (Brown and Taylor, 1988). Furthermore, the structural highs and volcanoes adjacent to Sumisu Jima, Torishima, and Sofu Gan, which bound the ends of the Sumisu and Torishima rifts, prevent sediment transport between the rift basins.

The continuity of the upper syn-rift reflector sequences throughout the inner and outer rift in the South Sumisu Basin is evidence for basin-wide sediment transport. The extremely high sedimentation rates have kept pace with subsidence rates and rift basin faulting, filling the differentially subsiding rift basin floor and maintaining a sediment plain, except for a few volcanic protrusions. There is no evidence for channel cut and fill in either the North Sumisu Basin or the South Sumisu Basin, suggesting that sediments are distributed throughout the basin by unconfined mass flows.

\section{CONCLUSIONS}

The data presented herein document the structural and stratigraphic evolution of Sumisu Rift and allow a detailed analysis of the pattern of strain in response to extension of an intraoceanic island arc. The 120 -km-long, $30-50-\mathrm{km}$-wide rift basin is bounded by normal fault zones dipping $60^{\circ}-75^{\circ}$ in the north and $25^{\circ}-50^{\circ}$ in the south. The rift is asymmetric and the largest offset border faults $(2-2.5 \mathrm{~km}$ throw) alternate sides along the length of the rift, on the arc side in the north but on the west side in the south.

Normal faults divide the region into four structural provinces across strike, from east to west: (1) the arc margin; (2) the inner rift, the locus of maximum subsidence; (3) the outer rift; and (4) the proto-remnant arc. Rift oblique transfer zones segment the rift along strike into four segments that exhibit different fault trends and uplift/subsidence patterns. Differential strain across the transfer zones is accommodated by interdigitating, rift-parallel faults and some cross-rift volcanism, rather than by strike-slip faults. No obvious correlations were observed between the transfer zones and preexisting cross-arc trends to either side of the rift.

The zigzag pattern of normal faults (average strikes $\mathrm{N} 23^{\circ} \mathrm{W}$ and $\mathrm{N} 5^{\circ} \mathrm{W}$ ) results from fault formation in orthorhombic symmetry in response to $\mathrm{N} 76^{\circ} \pm 10^{\circ} \mathrm{E}$ extension, approximately orthogonal to the volcanic arc. The curvilinear border fault zones exhibit both convex and concave dip slopes.

From estimates of extension ( $2-5 \mathrm{~km})$, the age of the rift ( 2 Ma) and the accelerating subsidence, we infer that Sumisu Rift is in the early syn-rift stage of backarc basin formation. Following an early sag phase, a half graben formed with a synthetically faulted, structural rollover facing large-offset border fault zones. The present, "full graben," stage is dominated by hanging-wall antithetic faulting, basin widening by footwall collapse, and a concentration of subsidence in the inner rift. The hanging wall collapses, but not necessarily as a result of border fault propagation from adjacent rift segments.

Whereas the border faults may penetrate the rheologically weak lithosphere $\left(T_{\mathrm{c}} \sim 3 \mathrm{~km}\right)$, many of the hanging-wall and footwall collapse structures are detached only a few kilometers below the seafloor. Backarc volcanism, usually erupted along faults, occurs in the rift and along the proto-remnant arc margin during both stages. The arc margin has been uplifted $1.1 \pm 0.5 \mathrm{~km}$ concurrently with $\sim 1.1$ $\mathrm{km}$ of rift basin subsidence.

Episodic eruptions of the arc volcanoes are the dominant sediment source; sediment is fed primarily into the northern and southern ends of the rift basin. Sediments are distributed throughout the region by eruptive events and redeposited in the rift basin by unconfined mass flows. Extremely high sedimentation rates (up to $6 \mathrm{~m} / 1000 \mathrm{yr}$ in the inner rift) have kept pace with syn-rift faulting, create a smooth basin floor, and result in sediment thicknesses that mimic the variable basin subsidence. Structural highs and volcanoes adjacent to the frontal arc volcanoes bound the ends of the rift and prevent sediment transport between adjacent rift basins.

A linear zone of weakness caused by the increased temperatures and crustal thickness along the arc volcanic line controls the initial locus of rifting. Rifts are better developed between the arc edifices; 

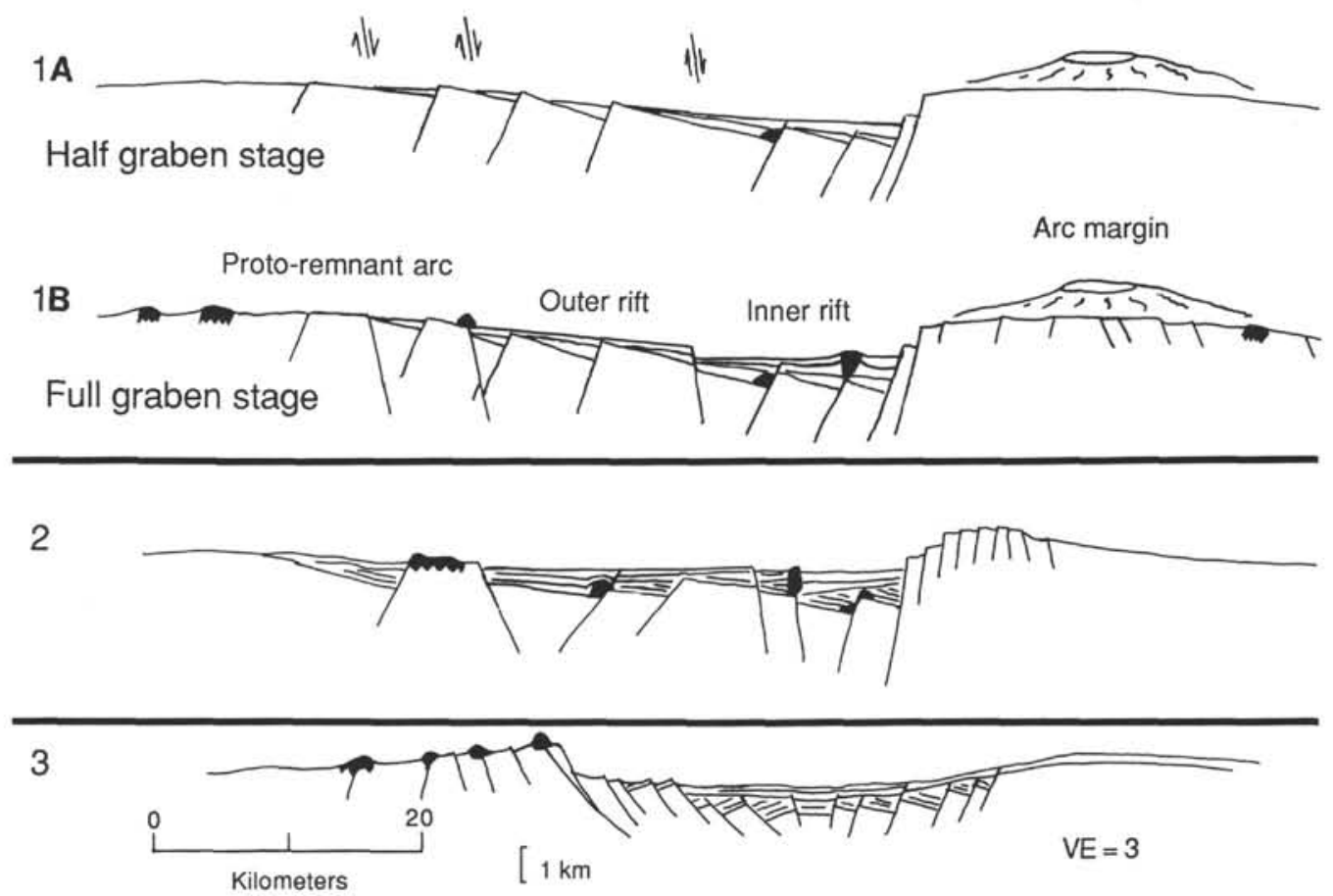

Figure 14. Schematic interpretation of the structural evolution of Sumisu Rift (1A and 1B), with two along-strike variations (2 and 3). See text for discussion.

intrusions may be accommodating extensional strain adjacent to the arc volcanoes.

\section{ACKNOWLEDGMENTS}

This work was supported by NSF Grant No. OCE86-14687 to B. Taylor, NSF Grant Nos. OCE-8700826 and OCE-8996141 to G. Moore, and a JOI/USSAC post-cruise grant to B. Taylor, G. Moore, P. Cooper, and A. Klaus. We would like to thank the Ocean Drilling Program for drilling in the Sumisu Rift; F. Martinez for extensive and insightful discussions regarding rifting; the Geological Survey of Japan for its scientific collaboration and hospitality; the officers, crew, and technicians of Fred Moore and Hakurei-maru; W. Barrens, P. Cooper, R. Horine, Y. Nakamura, and Y. Nogi for their help in acquiring the seismic data at sea; R. Horine for assistance in seismic data processing; J. and P. Wessel for fault azimuth and rose diagram programs; and N. Hulbirt and B. Bays for drafting. We thank two anonymous reviewers for their constructive reviews. This is SOEST Contribution No. 2604.

\section{REFERENCES}

Brown, G., and Taylor, B., 1988. Sea-floor mapping of the Sumisu Rift, Izu-Ogasawara (Bonin) Island Arc. Bull. Geol. Surv. Jpn., 39:23-38.

Chamot-Rooke, N., 1989. Le Bassin de Shikoku de sa formation a l'écaillage intra-océanique: évolution tectonique et méecanique [Ph.D. thesis]. Acad. de Paris, Univ. Pierre et Marie Curie.

de Charpal, O., Guennoc, P., Montadert, L., and Roberts, D. G., 1978. Rifting, crustal attenuation and subsidence in the Bay of Biscay. Nature, 275:706-711.

Ebinger, C. J., 1989a. Geometric and kinematic development of border faults and accommodation zones, Kivu-Rusizi Rift, Africa. Tectonics, 8:117-133,

, 1989b. Tectonic development of the western branch of the East African rift system. Geol. Soc. Am. Bull., 101:885-903.

Fryer, P., Taylor, B., Langmuir, C. H., and Hochstaedter, A. G., 1990. Petrology and geochemistry of lavas from the Sumisu and Torishima backarc rifts. Earth Planet. Sci. Lett., 100:161-178.
Gibbs, A. D., 1984. Balanced cross-section construction from seismic sections in areas of extensional tectonics. J. Struct. Geol., 5:153-160.

Gill, J., Torssander, P., Lapierre, H., Taylor, R., Kaiho, K., Koyama, M., Kusakabe, M., Aitchison, J., Cisowski, S., Dadey, K., Fujioka, K., Klaus, A., Lovell, M., Marsaglia, K., Pezard, P., Taylor, B., and Tazaki, K., 1990. Explosive deep water basalt in the Sumisu backarc rift. Science, 248:1214-1217.

Hochstaedter, A. G., Gill, J. B., Kusakabe, M., Newman, S., Pringle, M., Taylor, B., and Fryer, P., 1990. Volcanism in the Sumisu Rift. I. Major element, volatile, and stable isotope geochemistry. Earth Planet. Sci. Lett., 100:179-194.

Honza, E., and Tamaki, K., 1985. The Bonin Arc. In Nairn, A.E.M., Stehli, F. G., and Uyeda, S. (Eds.), The Sea (Vol. 7):The Ocean Basins and Margins: New York (Plenum Press), 459-502.

Hotta, H., 1970. A crustal section across the Izu-Ogasawara Arc and Trench. J. Phys. Earth, 18:125-141.

Hussong, D. M., and Uyeda, S., 1982. Tectonic processes and the history of the Mariana Arc: a synthesis of the results of Deep Sea Drilling Project Leg 60. In Hussong, D. M., Uyeda, S., et al., Init. Repts. DSDP, 60: Washington (U.S. Govt. Printing Office), 909-929.

Japanese DELP Research Group on Back-arc Basins, 1989. Report on DELP 1987 cruises in the Ogasawara area, parts I-VII. Tokyo Daigaku Jishin Kenkyusho Iho, 64:119-254.

Karig, D. E., 1971. Origin and development of marginal basins in the western Pacific. J. Geophys. Res., 76:2542-2561.

, 1975. Basin genesis in the Philippine Sea. In Karig, D. E., Ingle, J. C., Jr., et al., Init. Repts. DSDP, 31: Washington (U.S. Govt. Printing Office), 857-879.

Karig, D. E., and Moore, G. F., 1975. Tectonic complexities in the Bonin Arc system. Tectonophysics, 27:97-118.

Krantz, R. W., 1988. Multiple fault sets and three-dimensional strain: theory and application. J. Struct. Geol., 10:225-237.

Kuznir, N. J., and Park, R. G., 1987. The extensional strength of the continental lithosphere: its dependence on geothermal gradient, and crustal composition and thickness. In Coward, M. P., Dewey, J. G., and Hancock, P. L. (Eds.), Continental Extensional Tectonics. Spec. Publ., Geol. Soc. London, 28:35-52.

Leg 126 Shipboard Scientific Party, 1989. Arc volcanism and rifting. Nature, 342:18-20. 


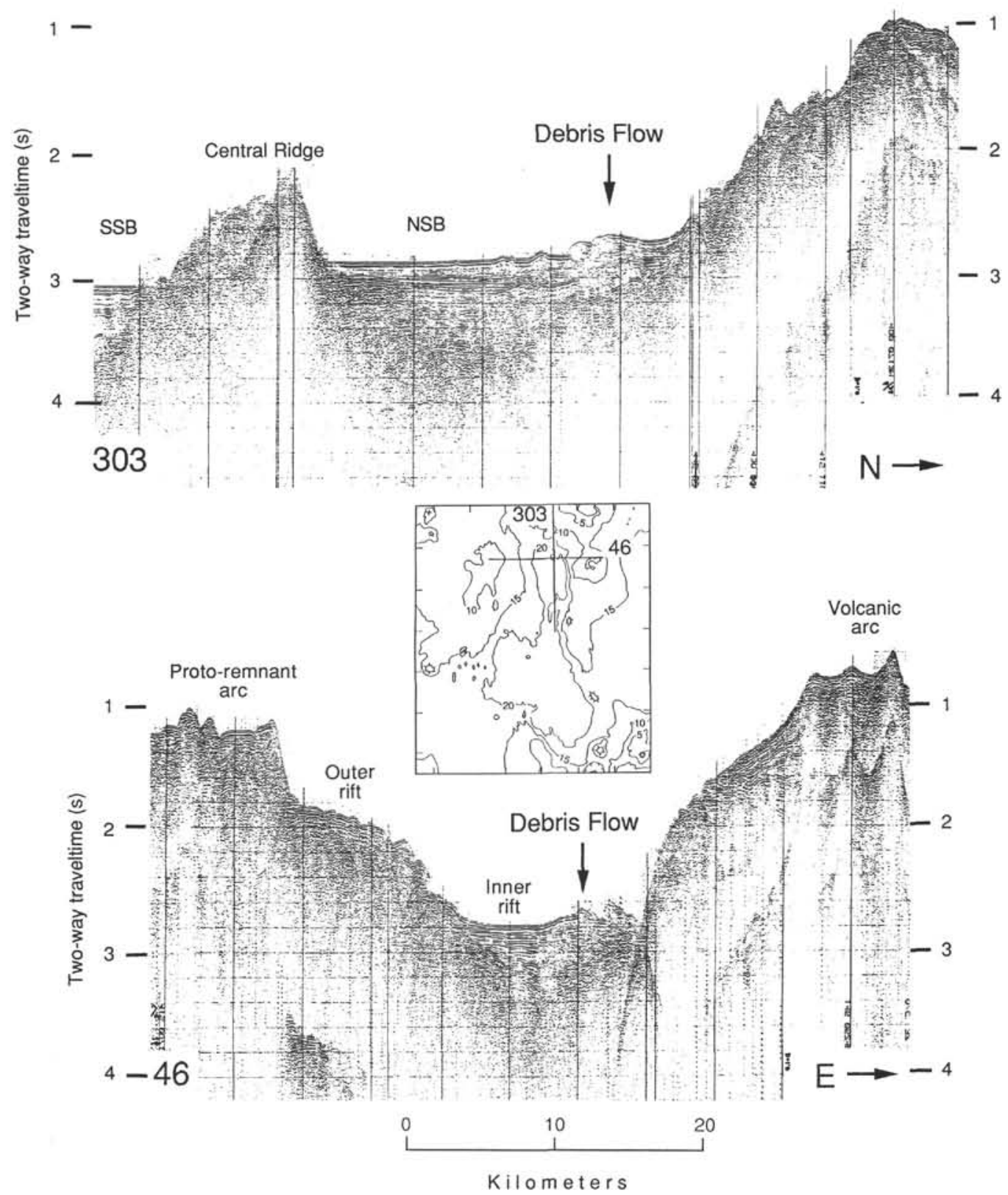

Figure 15. Single-channel seismic profiles (Geological Survey of Japan, Hakurei-maru, GH84-04) from the North Sumisu Basin. The north-south line 303 and the east-west line 46 intersect (arrow) over a large debris-flow deposit at the foot of the arc margin. The location of the seismic profiles is shown in the inset bathymetric map (same region as Fig. 3). Profile 303 also shows that the Central Ridge acts as a partial barrier to sediment transport from the North Sumisu Basin to the South Sumisu Basin.

Mogi, A., 1968. The Izu Ridge. In Hoshino, M. (Ed.), Fossa Magna. Geol. Soc. Jpn. (Tokyo), 217-221. (in Japanese)

Montadert, L., de Charpal, O., Roberts, D., Guennoc, P., and Sibuet, J.-C., 1979. Northeast Atlantic passive continental margins: rifting and subsidence processes. In Talwani, M., Hay, W., and Ryan, W.BF. (Eds.), Deep Drilling Results in the Atlantic Ocean: Continental Margins and Paleoenvironment. Am. Geophys. Union, Maurice Ewing Ser., 3:154-186.

Mrozowski, C. L., and Hayes, D. E., 1979. The evolution of the Parece Vela Basin, eastern Philippine Sea. Earth Planet. Sci. Lett., 46:49-67.

Murakami, F., 1988. Structural framework of the Sumisu Rift, Izu-Ogasawara Arc. Bull. Geol. Sunv. Jpn., 39:1-21.

Natland, J. H., and Tarney, J., 1982. Petrologic evolution of the Mariana Arc and backarc basin system: a synthesis of drilling results in the South Philippine Sea. In Hussong, D. M., Uyeda, S., et al., Init. Repts. DSDP, 60: Washington (U.S. Govt. Printing Office), 877-908.
Nishimura, A., and Murakami, F., 1988. Sedimentation of the Sumisu Rift, Izu-Ogasawara Arc. Bull. Geol. Surv. Jpn., 39:39-61.

Oertel, G., 1965. The mechanism of faulting in clay experiments. Tectonophysics, 2:343-393.

Packham, G. H., and Falvey, D. A., 1971. An hypothesis for the formation of marginal seas in the western Pacific. Tectonophysics, 11:79-109.

Reches, Z., 1983. Faulting of rocks in three-dimensional strain fields. II: Theoretical analysis. Tectonophysics, 95:133-156.

Reches, Z., and Dieterich, J. H., 1983. Faulting of rocks in three-dimensional strain fields. I: Failure of rocks in polyaxial, servo-control experiments. Tectonophysics, 95:111-132.

Rosendahl, B. R., 1987. Architecture of continental rifts with special reference to East Africa. Annu. Rev. Earth Planet. Sci., 15:445-503.

Sibuet, J.-C., Letouzey, J., Barbier, F., Charvet, J., Foucher, J.-P., Hilde, T.W.C., Kimura, M., Ling-Yun, C., Marsett, B., Müller, C., and Stephan, 


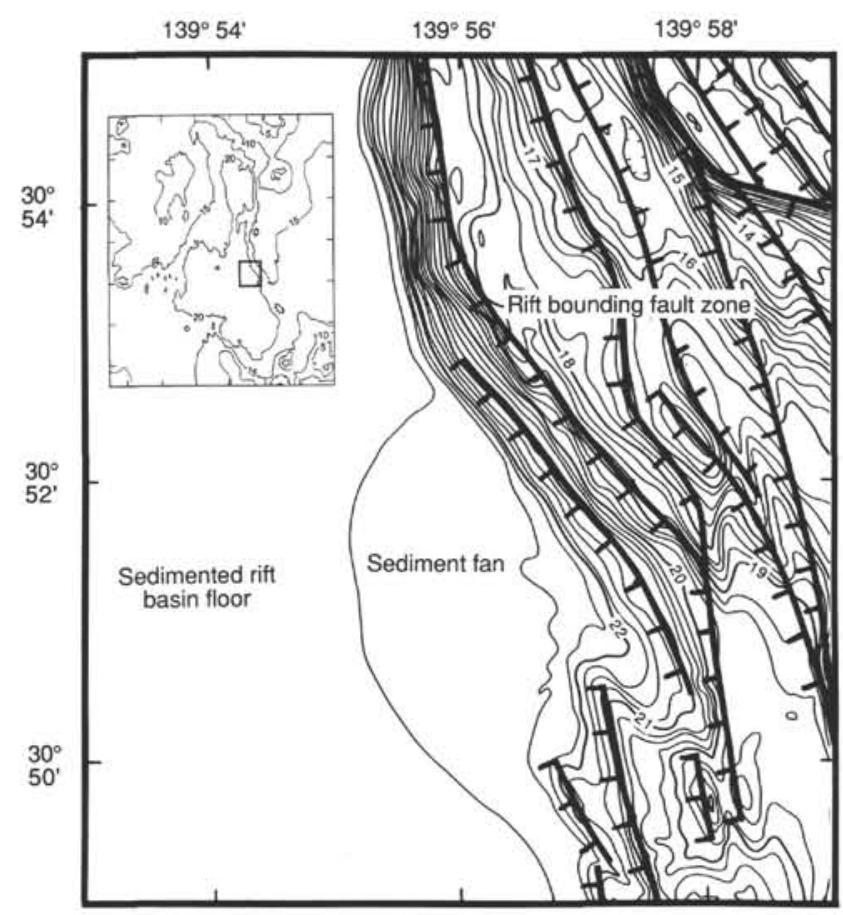

Figure 16. SeaBeam bathymetric map ( $25-\mathrm{m}$ contour interval, labeled in hundreds of meters) and normal faults along the eastern border fault zone. A small sediment fan extends $2 \mathrm{~km}$ onto the rift basin floor. The map location is shown on the inset bathymetric map (same region as Fig. 3).

J.-F., 1987. Back arc extension in the Okinawa Trough. J. Geophys. Res., 92:14041-14063.

Steckler, M. S., and ten Brink, U. S., 1986. Lithospheric strength variations as a control on new plate boundaries: examples from the northern Red Sea. Earth Planet. Sci. Lett., 79:120-132.

Tamaki, K., 1985. Two modes of back-arc spreading. Geology, 13:475-478.
Taylor, B., Brown, G., Fryer, P., Gill, J., Hochstaedter, F., Hotta, H., Langmuir, C., Leinen, M., Nishimura, A., and Urabe, T., 1990a. ALVINSeaBeam studies of the Sumisu Rift, Izu-Bonin Arc. Earth Planet. Sci. Lett., 100:127-147.

Taylor, B., Brown, G., Hussong, D., and Fryer, P., 1988a. SeaMARC II bathymetry, Sumisu and Torishima rifts, Izu-Ogasawara island arc, 1:200,000. Mar. Geol. Map Ser, Geol. Surv. Jpn., Tsukuba, 31. 1988b. SeaMARC II sidescan acoustic imagery, Sumisu and Torishima rifts, Izu-Ogasawara island arc, 1:200,000. Mar. Geol. Map Ser., Geol. Surv. Jpn., Tsukuba, 31.

Taylor, B., Fujioka, K., et al., 1990. Proc. ODP, Init. Repts., 126: College Station, TX (Ocean Drilling Program).

Taylor, B., Hussong, D., and Fryer, P., 1984. Rifting of the Bonin Arc. Eos, 65:1006.

Taylor, B., and Karner, G. D., 1983. On the evolution of marginal basins. Rev. Geophys. Space Phys., 21:1727-1747.

Taylor, B., Moore, G., Klaus, A., Systrom, M., Cooper, P., and MacKay, M., 1990b. Multichannel seismic survey of the central Izu-Bonin Arc. In Taylor, B., Fujioka, K., et al., Proc. ODP, Init. Repts., 126: College Station, TX (Ocean Drilling Program), 51-60.

Taylor, B., and Shipboard Scientific Party, 1990. Introduction. In Taylor, B., Fujioka, K., et al., Proc. ODP, Init. Repts., 126: College Station, TX (Ocean Drilling Program), 5-11.

Vink, G. E., Morgan, W. J., and Zhao, W.-L., 1984. Preferential rifting of continents: a source of displaced terranes. J. Geophys. Res., 89:10072-10076.

Weissel, J. K., and Karner, G. D., 1989. Flexural uplift of rift flanks due to mechanical unloading of the lithosphere during extension. J. Geophys. Res., 94:13919-13950.

Wright, I., Carter, L., and Lewis, K., 1990. Gloria survey of the oceanic-continental transition of the Havre-Taupo back-arc basin. Geo-Mar. Lett., 10:59-67.

Yamazaki, T., 1988. Heat flow in the Sumisu Rift, Izu-Ogasawara (Bonin) Arc. Bull. Geol. Surv. Jpn., 39:63-70.

Date of initial receipt: 7 January 1991

Date of acceptance: 19 July 1991

Ms 126B-158 